\title{
El fortín romano tardo-republicano del Tossal de la Cala (Benidorm, Alicante). Autopsia y reinterpretación de un yacimiento histórico*
}

\author{
The late-republican Roman fortlet of Tossal de la Cala \\ (Benidorm, Alicante). Examination and reinterpretation \\ of a historical site
}

\author{
Sonia Bayo Fuentes \\ Arqueóloga (Elche) \\ sonia.bayo@ua.es - ORCID iD: https://orcid.org/0000-0001-8864-6524 \\ Jesús Moratalla Jávega \\ INAPH, Universidad de Alicante \\ jesus.moratalla@ua.es - ORCID iD: https://orcid.org/0000-0003-0227-6150 \\ Ángel Morillo Cerdán \\ Universidad Complutense de Madrid \\ amorillo@ucm.es - ORCID iD: https://orcid.org/0000-0003-2139-0346 \\ Feliciana Sala Sellés \\ INAPH, Universidad de Alicante \\ feliciana.sala@ua.es - ORCID iD: https://orcid.org/0000-0003-1644-8611
}

Enviado: 04-06-2020. Aceptado: 07-07-2020. Publicado online: 30-09-2021

Cómo citar este artículo / Citation: Bayo Fuentes, S., Moratalla Jávega, J., Morillo Cerdán, Á. y Sala Sellés, F. (2021). "El fortín romano tardo-republicano del Tossal de la Cala (Benidorm, Alicante). Autopsia y reinterpretación de un yacimiento histórico". Archivo Español de Arqueología, 94, e16. DOI: https://doi.org/10.3989/ aespa.094.021.16

RESUMEN: En este trabajo presentamos cómo se ha ido recuperando la información de las excavaciones antiguas en el Tossal de la Cala e interpretado a la luz de los datos obtenidos en nuestras excavaciones (2013-2020), realizadas mediante convenio de colaboración con el Ayuntamiento de Benidorm. El final del proceso ha sido, primero, la recuperación de un yacimiento que se creía arrasado y, seguidamente, la caracterización fundamentada de un tipo de fortificación tardo-republicana de pequeña extensión inédito en la Hispania de la conquista.

\footnotetext{
* El estudio del Tossal de la Cala continúa en el proyecto HAR2016-76917-P, dirigido por F. Sala Sellés; su puesta en valor se está realizando con fondos FEDER concedidos al Ayuntamiento de Benidorm. En el presente estudio colabora asimismo el proyecto "Paisaje y territorio militarizado en la Hispania romana: movilidad y transferencia cultural (ss. II a. C.-IV d.C.)” (HAR2017-85929-P), dirigido por Á. Morillo Cerdán y C. Blázquez Cerrato. Ambos proyectos han sido concedidos por el Ministerio de Economía, Industria y Competitividad y financiados por la Agencia Estatal de Investigación (AEI) y el Fondo Europeo de Desarrollo Regional (FEDER).
} 
Palabras clave: Arqueología militar romana; Sertorio; guerras civiles romanas; Contestania ibérica; castellum.

ABSTRACT: In this article we present how the information from the old excavations at Tossal de la Cala has been recovered and reinterpreted in the light of the data obtained in our excavations (2013-2020). This work was carried out through a collaboration agreement with Benidorm City Council. The end of the process has resulted in, firstly, the recovery of a site that was believed to have been destroyed and, secondly, good evidence for the nature of a small type of late-republican fortification previously unknown in the conquest of Hispania.

Keywords: Roman military archaeology; Sertorius; Roman civil wars; Iberian Contestania; castellum.

Copyright: (C) 2021 CSIC. Este es un artículo de acceso abierto distribuido bajo los términos de la licencia de uso y distribución CreativeCommons Reconocimiento 4.0 Internacional(CC BY 4.0).

\section{LA HISTORIOGRAFÍA Y EL PROYECTO SERTORIO}

Tossal de la Cala (Benidorm), Cap Negret (Altea), Penyal d'Ifac (Calp) y Punta de la Torre (Moraira-Teulada) son yacimientos de reducida extensión construidos sobre promontorios de la costa norte de
Alicante, con pequeñas calas a sus pies aptas para el refugio de naves. Se localizan al sur del cabo de la Nau y mantienen conexión visual entre ellos, ejerciendo un extraordinario control de ese tramo del litoral. Penya de l'Àguila (Dénia) y Passet de Segària (Benimeli) se sitúan al norte del cabo, sobre cimas ligeramente alejadas de la costa, pero con una gran

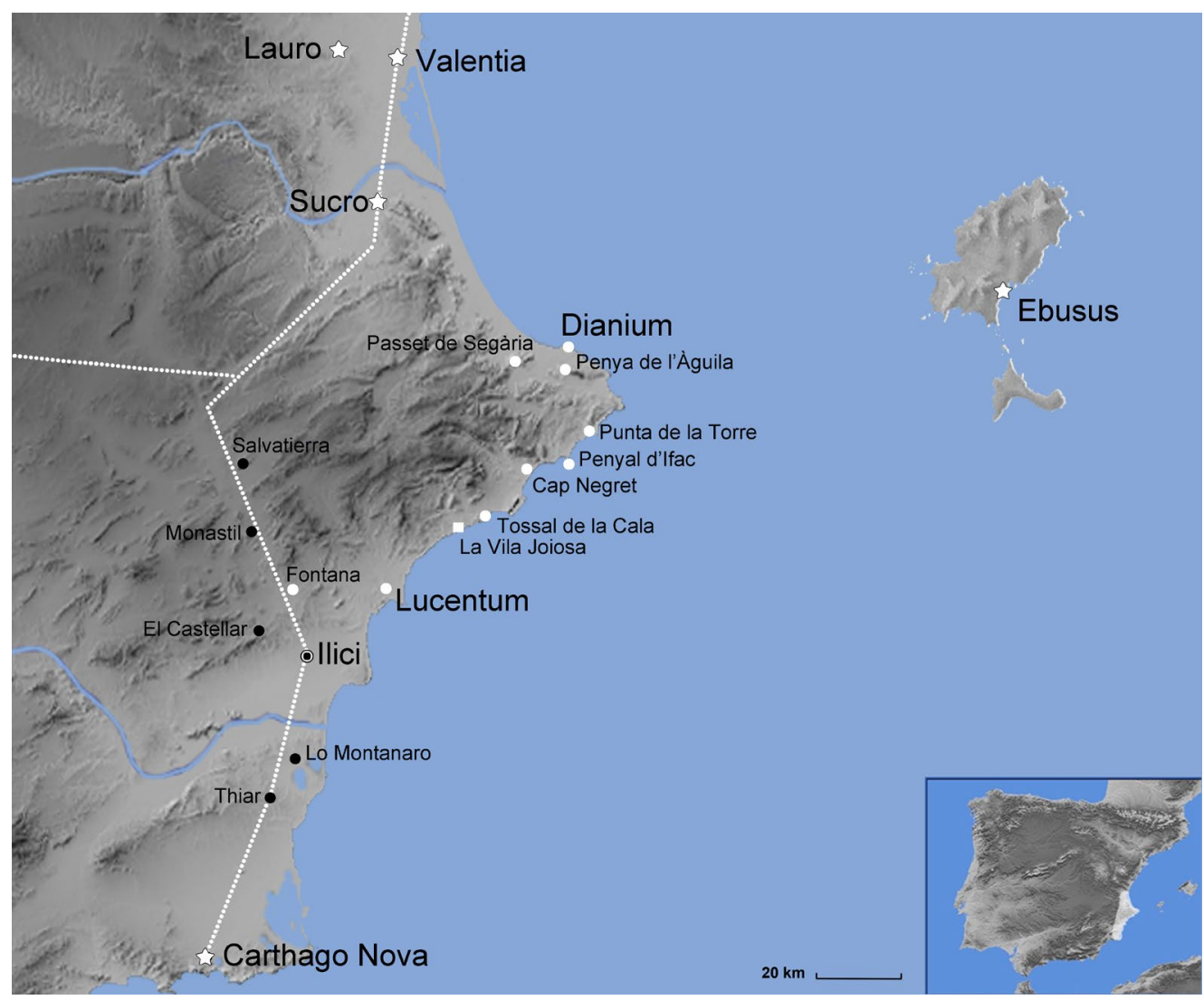

Figura 1. Cartografía histórica del conflicto sertoriano en torno al cabo de la Nau, indicando los fortines y yacimientos de cronología sertoriana (círculos blancos), el campamento de La Vila Joiosa (cuadrado blanco), los yacimientos de posible cronología cesariana y/o augustea (círculos negros) y las batallas o choques militares mencionados en las fuentes o demostrados arqueológicamente (estrella blanca) (elaboración propia). 
visibilidad sobre el golfo de Valencia (Fig. 1). Estos yacimientos fueron objeto de atención a lo largo del siglo XX por investigadores como J. Belda, M. Tarradell, A. Ramos, H. Schubart, E. Llobregat y F. García Hernández, datándolos entre los siglos II y I a. C. por la presencia de campaniense A y B y la ausencia de sigillata. Con la publicación de la Contestania Ibérica (Llobregat, 1972) se consolidaba la idea de pequeños poblados iberos tardíos, cuyos habitantes optaron por la seguridad de las cimas antes que por la cercanía de los terrenos agrícolas o de pastoreo. La abundante cerámica importada se explicaba por una localización costera favorable a los intercambios comerciales, en tanto que la existencia de numerario romano e ibérico se valoraba como el principio de su inserción en el sistema económico romano.

La arqueología ibérica alicantina experimenta un notable avance durante las últimas décadas del siglo XX e inicios del XXI, especialmente en el conocimiento de las fases antigua y plena, pero la fase final continuó siendo un asunto pendiente pese a los estudios planteados desde la perspectiva del poblamiento (Abad, 1987; Moratalla, 2005), o desde los contextos materiales (Sala, 2003). En estos trabajos se destacaba la situación liminal de los yacimientos y el elevado número de ánforas y vajilla fina itálica de época republicana. Años después, la revisión de los materiales de la excavación del padre Belda en el Tossal de la Cala cambió la percepción del yacimiento (Bayo, 2010), pues entre los hallazgos se reconocía armamento y $m i$ litaria romanos. La sospecha de que podía haber soldados apostados en el recinto ibérico abría un interesante campo de investigación, porque, entre otros aspectos, la presencia romana entre población local podía explicar el inicio de la romanización de la Contestania. Las posibilidades que ofrecía el estudio nos animaron a solicitar un proyecto de investigación en la convocatoria de 2009 del Subprograma de Investigación Fundamental no Orientada del Ministerio de Ciencia e Innovación, que continuamos en un segundo financiado por el Ministerio de Economía y Competitividad.

El estudio se aborda desde distintos puntos de vista: la cerámica y los militaria, las fortificaciones, la arquitectura y la geoestrategia derivada de unos enclaves litorales comunicados visualmente. Partíamos de una información desigual para cada yacimiento, pues mientras que en algunos se había excavado, otros solo habían conocido rebuscas clandestinas, y los resultados han sido satisfactorios. La arqueología ha desvelado una realidad histórica que las fuentes escritas no mencionaban: el valor del tramo costero en torno al cabo de la Nau en las guerras sertorianas (Sala et al., 2014; Sala, Bayo y Moratalla, 2014).

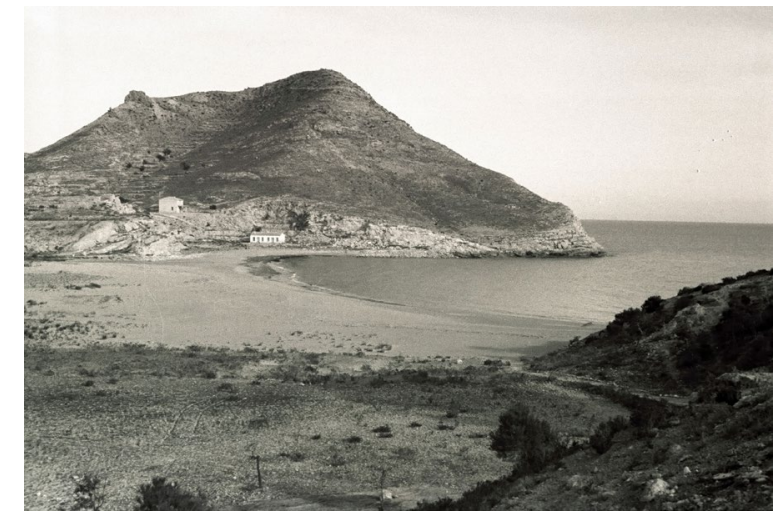

Figura 2. Imagen del Tossal tomada por F. Sánchez durante la visita al yacimiento de Belda y Schulten en 1943; en la base, la cala de Finestrat (fotografía Archivo Municipal de Alicante).

\section{LA EXCAVACIÓN DEL PADRE BELDA DE 1943}

El Tossal de la Cala cierra la ensenada de Benidorm por poniente, conformando una silueta icónica a cuyo abrigo queda la cala de Finestrat. Belda visitó por primera vez el lugar en mayo de $1935^{1}$, iniciando la primera exploración arqueológica de un paraje que por entonces estaría incólume. Por la noticia referida en la nota 1 parece que el detonante de la excavación fue la visita de Belda al yacimiento el 20 de enero de 1943 acompañado por Schulten y el fotógrafo alicantino Francisco Sánchez, quien dejó constancia de aquella excursión en las escasas fotografías de aquella década (Fig. 2). En diciembre de ese año Schulten menciona las excavaciones en una entrevista en el diario Información ${ }^{2}$, y el propio Belda indica que habían empezado en el verano de $1943^{3}$. No nos constan trabajos posteriores $\mathrm{y}$, por el contrario, sí conocemos un documento en el que el Comisario General de Excavaciones, Julio Martínez Santa-Olalla, ordena vehementemente que cesen las excavaciones amparándose en la falta de rigor metodológico ${ }^{4}$. Debemos suponer que, en consecuencia, se dio por finalizada la intervención de Belda.

Es el único excavador que conoce el yacimiento y su entorno sin alteraciones urbanísticas, por lo que los primeros datos de interés en sus escritos son los que refieren la topografía arqueológica del paraje. Señala la existencia de tres yacimientos, siendo los restos del

\footnotetext{
1 Información, 24-I-1943.

Información, 6-XII-1943.

Información, 17-XII-1944.

4 El documento, conservado en el Archivo Documental del MARQ, está fechado el 5 de marzo de 1946 y en él Santa-Olalla carga con dureza sobre los trabajos de Belda.
} 


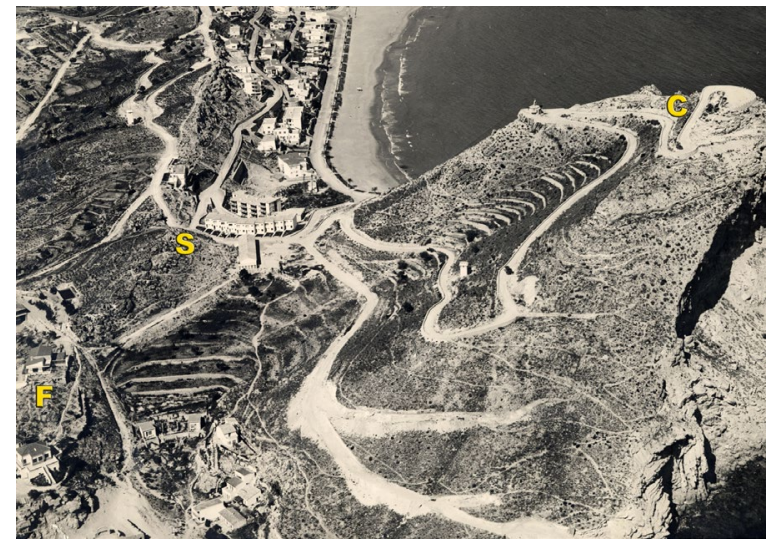

Figura 3. Imagen del Tossal de la Cala de los primeros años 60 con el santuario y la factoría todavía visibles a los pies del cerro (fotografía Archivo Histórico Municipal de Benidorm).

Tossal de la Cala los que denominó "castillejo ibérico". De los otros dos, su conocimiento empieza y acaba en Belda, pues cuando intervienen Tarradell y Ramos en 1956 apenas los mencionan. El "santuario" está localizado en el pequeño cerro cónico que se alza a los pies del Tossal, de unos $41 \mathrm{~m}$ de cota, junto al cuartel de carabineros que allí existía (Fig. 3). Aún se percibe el perfil elevado de la loma, pese a hallarse completamente urbanizada. No entraremos a debatir sobre si era santuario o necrópolis, como defendían Tarradell (1985, p. 117) y Llobregat (1972, p. 61), aunque se admite el carácter singular del yacimiento por los pequeños depósitos dispersos por la ladera norte donde aparecieron pebeteros de cabeza femenina (Belda, 1945) $)^{5}$. Localizamos la "factoría colonial" a unos $100 \mathrm{~m}$ al sudoeste del santuario en un terreno alargado y elevado unos $30 \mathrm{~m}$ por encima de la cala ${ }^{6}$. Según Belda (1950-1951, p. 80), era un asentamiento fortificado con una "doble muralla", "sembrado de fragmentos cerámicos correspondientes a los siglos IV y III a. C." . Hemos confirmado que la imagen publicada por García y Bellido (1945, lám. XXIII) con Schulten tomando notas frente a un lienzo semiciclópeo corresponde a este yacimiento.

Belda dedicó el mayor esfuerzo a la excavación del Tossal de la Cala exhumando un total de 27 es-

5 Belda recuperó siete piezas completas, sin huellas de combustión. Su conocimiento fue tan generalizado que sirvieron a A. M. Muñoz para ilustrar su tipo D, el de aletas o velo (Muñoz, 1963, p. 36).

6 En un reconocimiento superficial de los taludes de algunas áreas ajardinadas entre bloques de apartamentos efectuado en 2017 encontramos cerámica ibérica pintada y ánfora.

7 Información, 24-I-1943. tancias adosadas a una muralla. La estrategia seguida parece clara pues, una vez determinada la posición de la muralla, fue excavando las estancias adosadas, actuando en una superficie que rondaría los $1000 \mathrm{~m}^{2}$. Su intervención cuenta con importantes lagunas, pues no disponemos de documentación manuscrita o gráfica original, aunque sabemos que existió ${ }^{8}$, y de sus publicaciones tan solo la memoria presentada en 19501951 provee de algunos datos de interés.

\section{LA INTERVENCIÓN DE M. TARRADELL Y A. RAMOS DE 1956}

Al compás del arranque del desarrollismo turístico en la costa, en los primeros meses de 1956 se abre un camino en el Tossal hasta su cima9. El vial dividió el yacimiento en dos parcelas a un lado y otro del camino en su penúltima curva, que a partir de aquí denominaremos parcela oriental y occidental (Fig. 4) ${ }^{10}$. Esta actuación debió llegar a oídos de Ramos, que dio comunicación de los hechos a Tarradell, por entonces recién llegado a la cátedra de Arqueología de la Universidad de Valencia y delegado de zona del distrito universitario. En poco tiempo se puso en marcha la que podemos considerar primera intervención de urgencia en un yacimiento alicantino, de la que se daría una sintética información muchos años después (Tarradell, 1985). Al parecer, en ello tuvo mucho que ver el alcalde de Benidorm, Pedro Zaragoza, quien convenció a la propiedad de los terrenos, una constructora extranjera, para que permitiera las excavaciones (Tarradell, 1985, p. 114) $)^{11}$.

Gracias al hallazgo en 2012 del diario de campo de Ramos, al que más adelante nos referiremos, sabemos que concentraron el trabajo en la parcela oriental, más afectada por el camino, llegando a excavar un área de unos $350 \mathrm{~m}^{2}$. La estrategia seguida fue, con buen criterio, aumentar la porción excavada del yacimiento para obtener una mayor y más precisa documentación del mismo, ante el inminente riesgo de que las estructuras fueran arrasadas por construcciones modernas, como así fue.

8 Por el documento citado en nota 5 sabemos que la Comisaria General de Excavaciones contaba con un dosier fotográfico de las excavaciones del Padre Belda, pero ignoramos si este documento existe a día de hoy.

9 El fotograma del Vuelo Americano está datado el 4 de julio de 1956.

10 En el momento de redactar estas líneas nos encontramos inmersos en los trabajos de puesta en valor que tienen por objeto reintegrar ambas parcelas en un único conjunto.

11 Los materiales se depositaron en el Ayuntamiento de Benidorm, salvo las monedas -siete en total- que se llevaron al Museo Arqueológico Provincial de Alicante. 


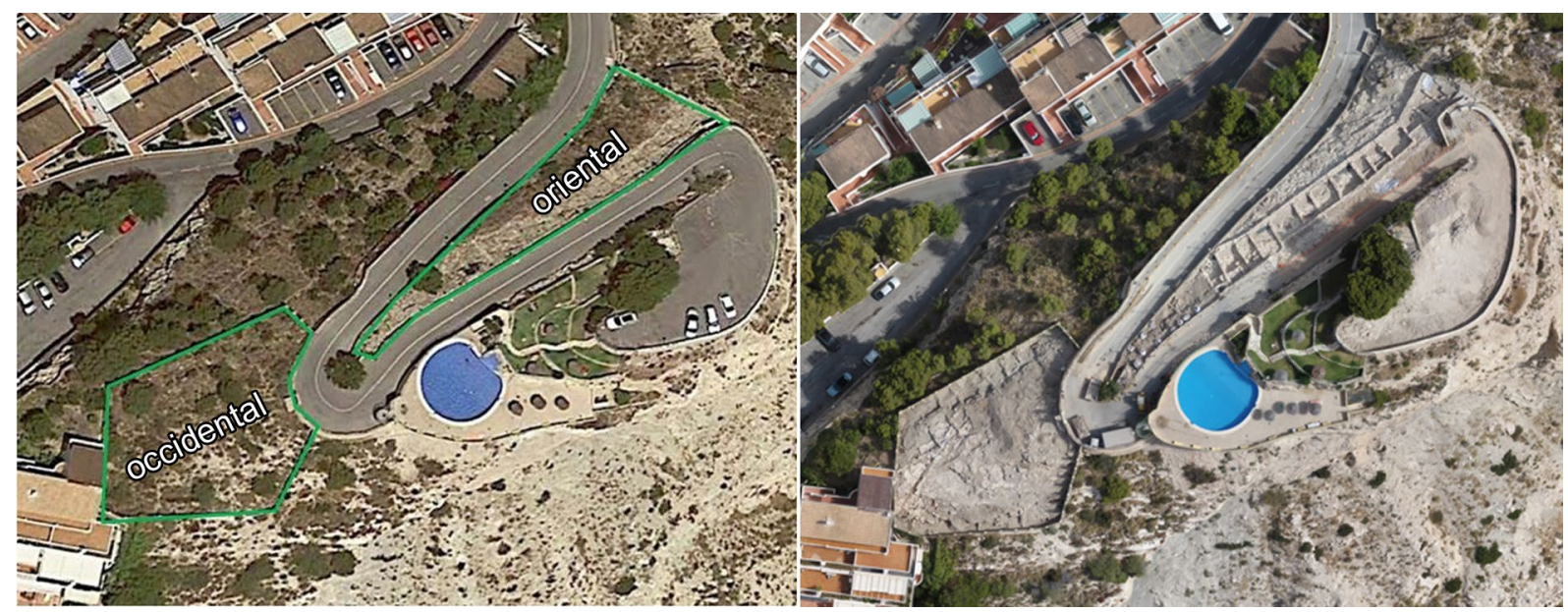

Figura 4. Foto aérea con indicación de las dos parcelas tomada al inicio de nuestros trabajos (izq.) y misma imagen tomada durante los trabajos de 2019-2020 (dcha.) (elaboración propia).

La publicación incluye, por primera y única vez, un plano y varias secciones de los restos arquitectónicos exhumados, donde ya se perciben con nitidez cuerpos constructivos en batería, con estancias dispuestas siguiendo la inclinación de la ladera e insertos en lo que interpretan como una calle alta y otra baja. El plano no se ubica en el conjunto del yacimiento, de modo que cuando se publica en 1985 nadie reconoce en él las 13 estancias que quedaron visibles en la parcela oriental tras las excavaciones (Fig. 5). Tarradell tenía en mente el urbanismo geomórfico del oppidum ibérico de Sant Miquel de Llíria (Valencia) y, así, el lugar encastillado de Belda fue sustituido por un oppidum con urbanismo en ladera. Con todo, no manifiestan diferencias respecto a la propuesta cronológica, pues manejan la horquilla de los siglos II-I a. C. y, como Belda, piensan que a partir del 50-40 a. C. el lugar ya no se habita (Tarradell, 1985, p. 115). En la imagen aérea del Vuelo Interministerial, al parecer de $1978^{12}$, el cerro sigue sin urbanizar y en mayo de 1984 la situación seguía igual, de acuerdo con el fotograma del Vuelo Nacional de 1980-1986 ${ }^{13}$. Estamos a las puertas de la excavación de F. García Hernández y han pasado ya casi treinta años de la actuación de Tarradell y Ramos.

\section{LA EXCAVACIÓN DE F. GARCÍA HERNÁNDEZ DE 1984}

En el ínterin que media hasta la tercera y última intervención en el Tossal de la Cala, solo es reseñable

12 La fecha propuesta procede de un estudio de carácter geográfico (Olcina, 2004), el cual señala que están utilizando fotogramas de ese año para estudiar la costa alicantina.

13 Ambos fotogramas han sido consultados en la página del Instituto Geográfico Nacional http://fototeca.cnig.es/

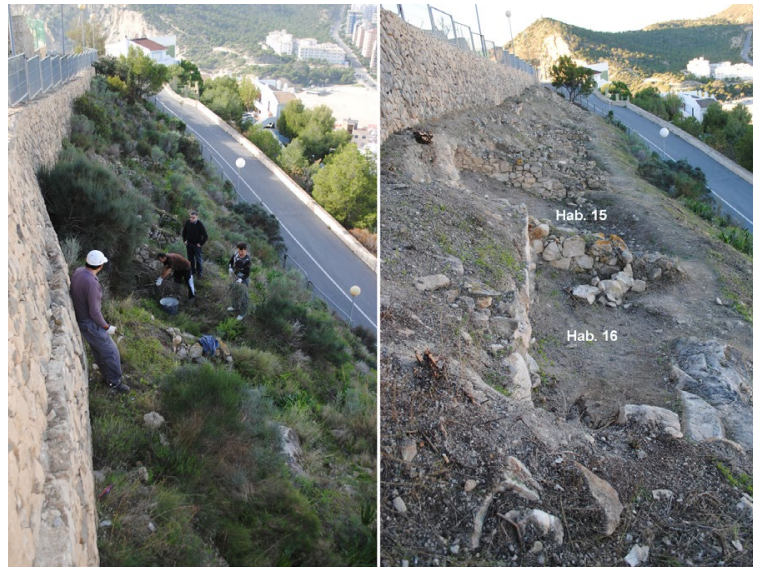

Figura 5. Imagen de las estancias visibles en la parcela oriental antes y después de su limpieza en 2012 (fotografía propia).

la aportación de E. Llobregat sobre el yacimiento en su Contestania Ibérica (Llobregat, 1972, pp. 59-62) ${ }^{14}$, pues su hipótesis - "un poblado ibérico fortificado de baja época"- sentará las bases de la opinión científica sobre la naturaleza del asentamiento $y$, aún más, pasa a erigirse como modelo de asentamiento ibérico contestano de ese momento. En realidad, Llobregat no difiere de los argumentos de su maestro Tarradell. Por un lado, mantiene la cronología, todo en un único nivel de ocupación; por otro, sobre los restos de materiales

14 En realidad, existe otra referencia visual que roza lo folklórico: el camino de ascenso al mirador aparece en varios fotogramas de la película Un beso en el puerto, protagonizada por Manolo Escobar y rodada en 1964. En ellos no se observa detalle alguno del yacimiento, pero sí se ve que el camino era de tierra y tenía poco más de $2 \mathrm{~m}$ de ancho. 
más antiguos plantea la posibilidad de que procedieran de la factoría ubicada al pie del cerro.

La excavación de García Hernández va al unísono de la definitiva y completa reordenación del cerro, que lo convertirá en solar de la urbanización "Montbenidorm" a partir de 1985, para lo cual era necesario delimitar los restos arqueológicos ${ }^{15}$. La tarea se realizó en agosto de 1984, consistiendo en abrir cinco sondeos en la ladera por debajo de los restos visibles (García Hernández, 1986). Los sondeos resultaron negativos por lo que, estando el más alto a una cota de $85 \mathrm{~m}$, se consideró que el asentamiento quedaba por encima y se podían liberar los terrenos inferiores. También realizó la limpieza de las 13 estancias de la parcela oriental numerándolas a su criterio, ya que la publicación de Tarradell todavía no había aparecido ${ }^{16}$. Aunque la

15 La orden ejecutoria procede de la recién creada Dirección General de Patrimonio Histórico de la Generalitat Valenciana, que dio por buenos los límites propuestos por el promotor. No obstante, hubo voces desde la Universidad de Alicante (Yáñez, 2000, p. 44) que consideraron incorrecta tal delimitación. De hecho, es innegable que posteriormente la urbanización cercenó su extremo occidental y también construyó una piscina cerca de la cima.

16 Hoy sabemos que las estancias intervenidas por García Hernández se corresponden con la 6 a 17 de Tarradell.

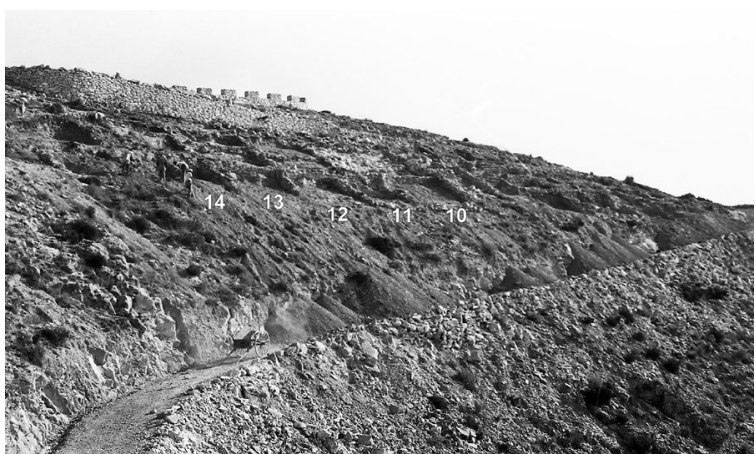

Figura 6. Imagen de la excavación de 1956 tomada por A. Ramos con indicación de estancias reconocibles; en primer plano, el camino abierto por la pala y, arriba, el mirador de la cima (fotografía F.U.I.A. L’Alcúdia)

mayoría de los departamentos los encuentra excavados por completo, documenta algunos equipamientos como bancadas y restos de pavimentos. Solo en un par de casos parece que toca estratos que parecen estar en posición primaria, sin duda el estrato de regularización de la roca por debajo del nivel de circulación, que no terminaron de rematar en las primeras excavaciones, y donde encuentra fragmentos cerámicos y piezas metálicas. Con ello se resumiría la intervención

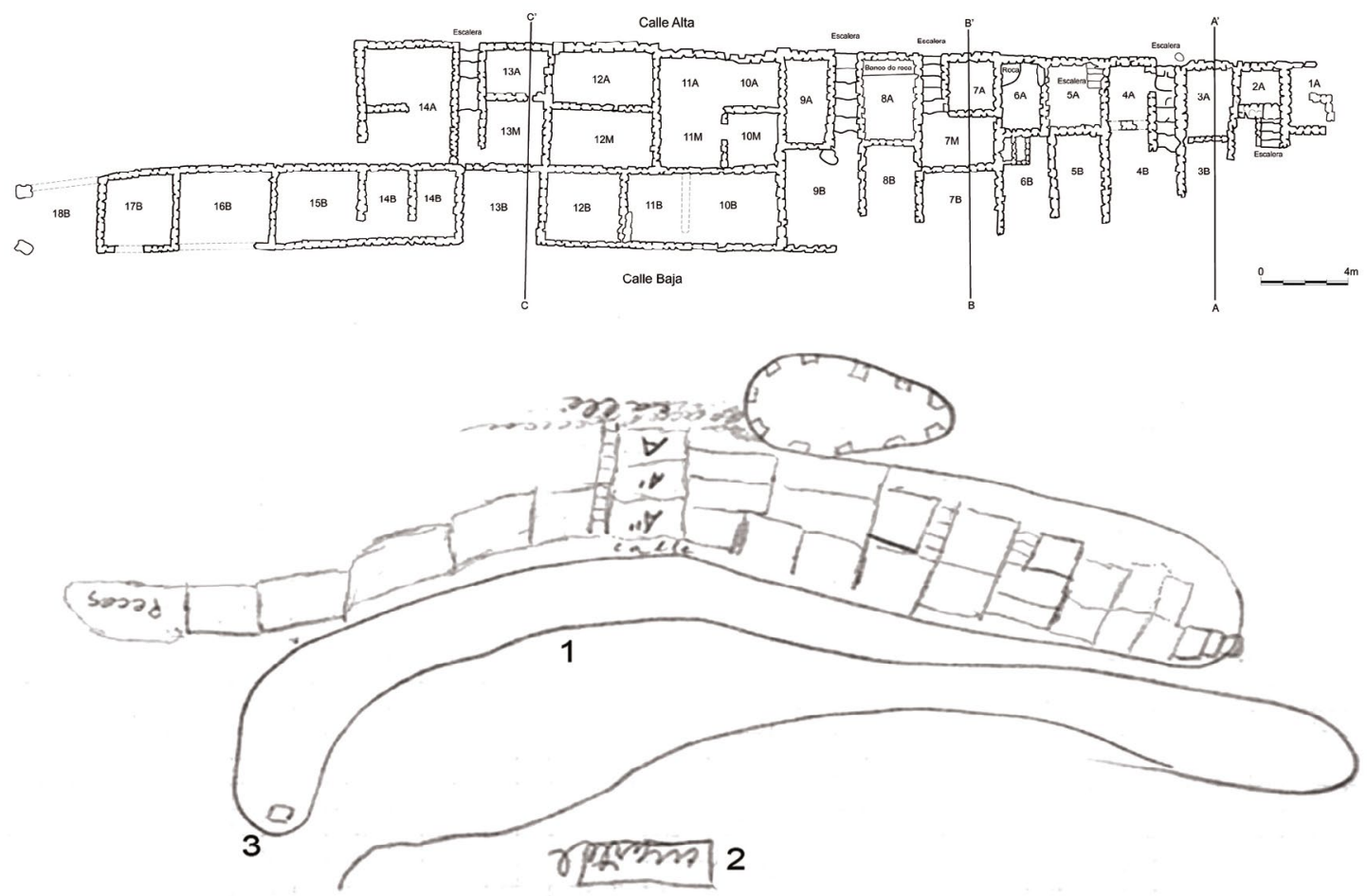

Figura 7. Plano de Tarradell publicado en 1985 y croquis de Ramos en el diario de 1956. En éste se indica el camino abierto por la pala (1), el cuartel de donde arranca el mismo (2) y la ermita en la segunda curva (3). Las estancias A, A' y A" son el conjunto 13A-13M-13B de Tarradell, sobre las que discurre la calle (elaboración propia a partir de los originales) 
de García Hernández, que no altera lo más mínimo la cronología ya conocida. Después de él y hasta 2013, la única intervención digna de ser referida es una nueva limpieza de las 13 estancias y la elaboración de la planimetría general del yacimiento en 1997 por E. Díes Cusí para el Ayuntamiento de Benidorm, muy útil por otro lado, pues además de las estancias de la parcela oriental incorpora los muros visibles en la parcela occidental, unos restos que, como veremos, son parte de las 27 estancias que excavara Belda ${ }^{17}$.

\section{EL REDESCUBRIMIENTO DEL YACIMIENTO EN 2013}

Iniciamos la colaboración con el Ayuntamiento de Benidorm en otoño de 2012 volviendo a limpiar las estancias del solar oriental. La investigación habría quedado estancada en este punto si no es por el hallazgo del diario de campo de 1956 y dos rollos de negativos en el archivo personal de Ramos Folqués ${ }^{18}$ (Fig. 6), un precioso documento que ha sido definitivo para comprender los trabajos arqueológicos realizados por ellos y por Belda, paliando en parte la merma de información con la que veníamos trabajando. Además de dibujos a mano alzada de los hallazgos, el diario aporta el croquis de las estancias donde estaban interviniendo, las mismas del plano de Tarradell y, puesto que incluye referencias hoy todavía existentes, concluimos que las 13 estancias visibles son las bajas del plano de 1985 (Fig. 7).

Ramos anota en el diario que intervienen en las estancias situadas por "detrás de lo excavado por Belda", con lo que las estancias bajas del plano de Tarradell son parte de las 27 excavadas por Belda. Por ello, cuando en 2013 el Ayuntamiento de Benidorm nos plantea retomar los trabajos en el yacimiento, el primer objetivo es un lomo de tierra que recorre las estancias cerrándolas por su lado septentrional: si era cierto que Belda había excavado las estancias pegadas a la muralla, como afirmaba en 1950-1951, y eran las bajas del plano de Tarradell, como señalaba Ramos en su diario, ese lomo debía contener los restos de la muralla cubiertos por las terreras de las excavaciones, lo que se confirmó al tercer día de campaña. Entendemos ahora que el plano de 1985 no incluyera la muralla; sin duda Tarradell y Ramos solo vieron su paramento interno y cerraron las estancias con un simple muro.

17 Agradecemos al autor la deferencia de cedernos la documentación elaborada entonces.

18 Documentos custodiados por la Fundación Arqueológica L'Alcúdia de la Universidad de Alicante, a la que agradecemos, en especial a Ana Ronda, la deferencia de compartir esta información con nosotros.

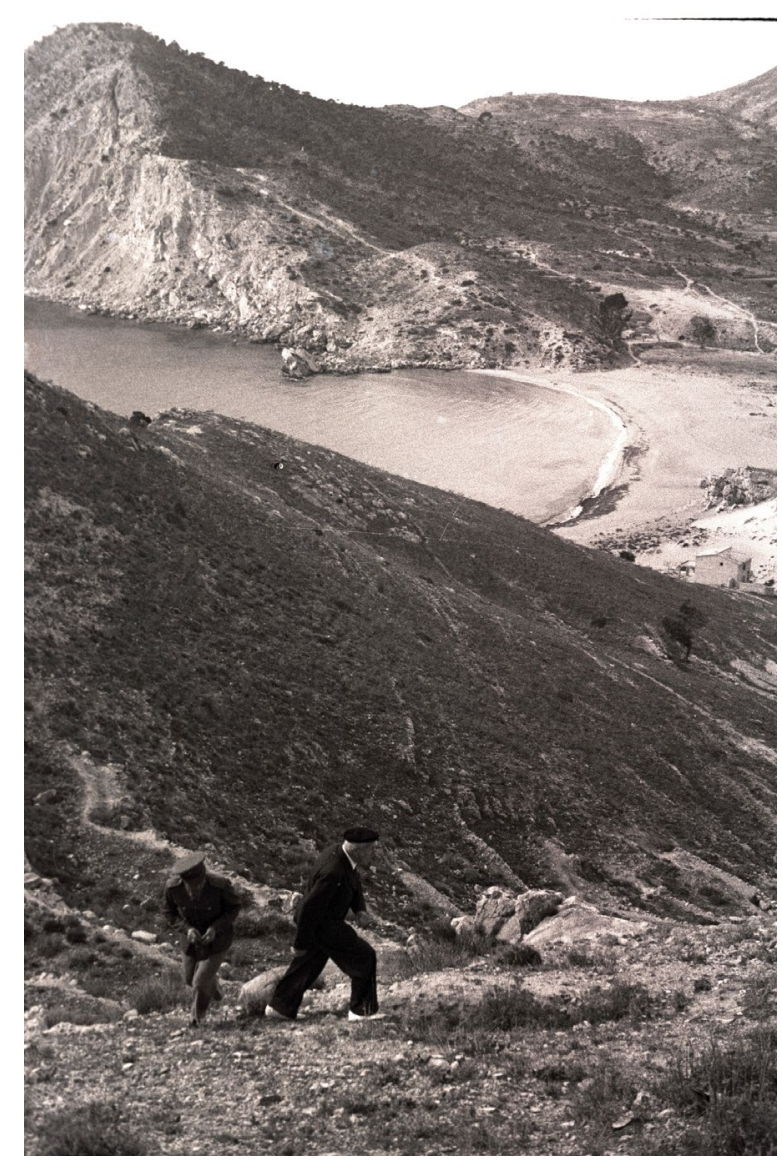

Figura 8. Schulten ascendiendo al Tossal de la Cala en enero de 1943 por el lado oriental del cerro más accesible. Nótese al fondo la acentuada pendiente de la ladera occidental (fotografia Archivo Municipal de Alicante).

Entre 2013 y 2016 documentamos los restos de esas 13 estancias y analizamos sus relaciones estratigráficas, comprobando que todo el conjunto se construye de una vez. Seguíamos sin ver las estancias superiores, que presumíamos ocultas bajo el ensanche del camino hecho con la urbanización, pero ya era posible intuir lo esencial de la trama arquitectónica: una muralla perimetral de escaso grosor servía de muro zaguero a una sucesión de estancias en batería, a las que se accedía por otro departamento dispuesto a una altura mayor, abierto a una calle, siendo las "escalerillas" que mencionaban tanto Belda como Tarradell equipamientos interiores que comunicaban la estancia alta con la baja. Confirmamos que el enclave se construye ex novo sobre la roca del cerro y que presenta un único horizonte de ocupación que no llega a la mitad del siglo I a. C. (Bayo, 2014). El numerario del siglo II a. C., que hizo a los primeros excavadores establecer la cronología inicial en esa centuria, se estaba usando en ese momento con pleno valor de cambio (Doménech, 2014, pp.95-96). 


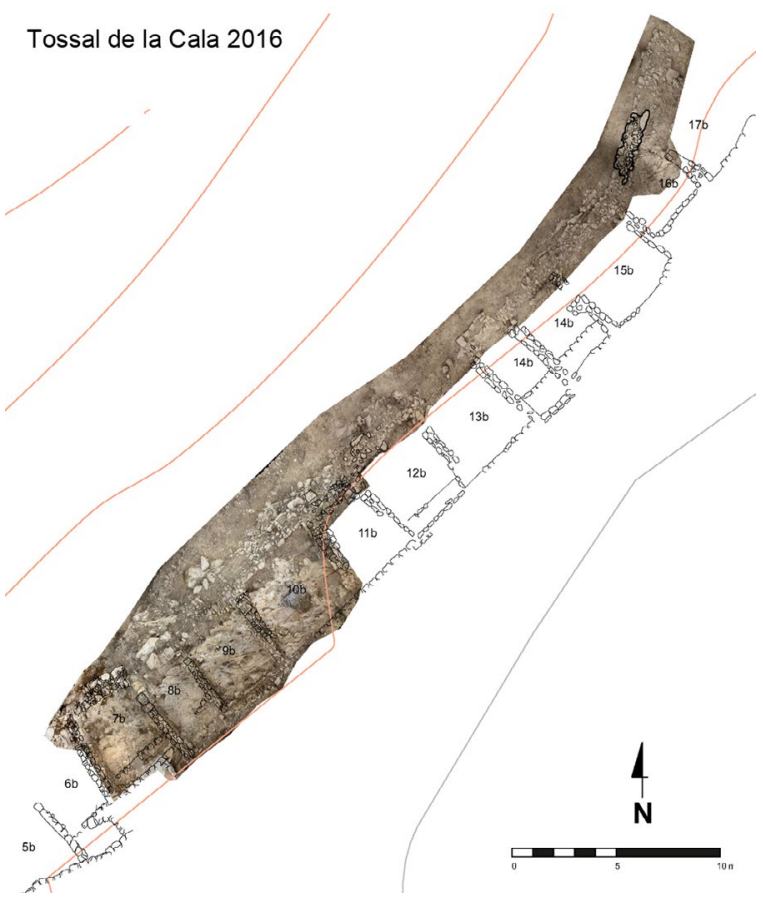

Figura 9. Planta fotogramétrica final de la campaña de 2016 con la cortina del lienzo septentrional de la muralla al descubierto (elaboración propia).

\section{LA ELECCIÓN DEL EMPLAZAMIENTO Y LA FORTIFICACIÓN}

Hoy sabemos que el Tossal de la Cala fue un recinto fortificado de aproximadamente 0,5 ha de extensión ubicado en la cima del promontorio costero, el cual estaría delimitado por una muralla levantada en sus vertientes norte y oeste, e innecesaria en el resto de vertientes al estar definidas por un acantilado vertical de $100 \mathrm{~m}$ de altura. El recinto se emplaza sobre una cresta rocosa en la umbría del cerro. Su acceso era complicado por la acusada pendiente de la ladera (Fig. 8 ), imposible para vehículos a ruedas, por lo que en su elección primaron las bondades estratégicas del cerro. Desde su cima, se percibe nítidamente toda la bahía de Benidorm y, a resguardo de ella, la inmediata cala de Finestrat; en el centro, como referencia inequívoca, la isla de Benidorm, cuyo control proyectaba hacia el mar el carácter geoestratégico del promontorio. Este paisaje marítimo explica la elección del cerro en un entorno árido, con escasa habitabilidad.

Belda describió la muralla como una "sencilla muralla de mampostería de estilo primitivo [...] de un metro de espesor", que discurría en paralelo a un "ovalado banco de roca" que rodeaba la cima del cerro (Belda, 1950-1951, p. 82). No entendíamos a qué se refería con un banco de roca hasta que encontramos la foto de 1943 (Fig. 2). En la imagen se aprecia una franja clara recorriendo la cima de este a oeste que parecía un escarpe rocoso; en la foto de la figura 3 se observa mejor el escarpe doblando por el límite occidental hacia el acantilado para formar esa línea ovalada que Belda menciona. Lo hemos exhumado en las excavaciones recientes, comprendiendo que la muralla se construyera casi sobre la vertical del escarpe "siempre algo desplazada hacia dentro" (Belda, 1950-1951, p. 82), pues el alzado de la muralla gana en altura al añadir los 2-3 m del escarpe.

Tras descubrir en la parcela oriental una cortina de unos $46 \mathrm{~m}$ de longitud del lienzo septentrional (Fig.

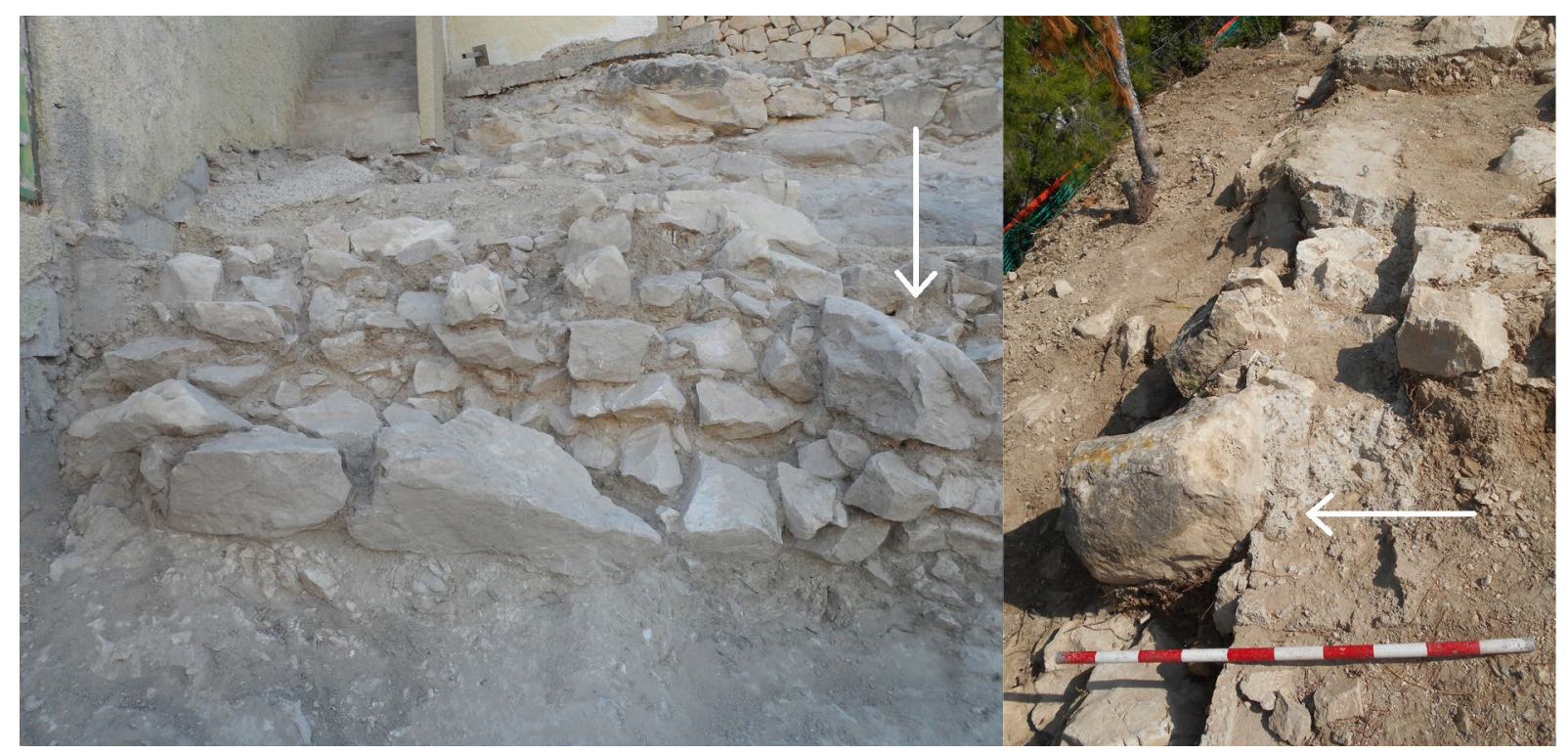

Figura 10. A la izquierda tizón dispuesto a la altura de la estancia 17 y a la derecha el hallado entre las estancias 20-21. En la imagen de la izquierda la fuerte erosión inclinada he dejado a la vista el emplecton del relleno (fotografía propia). 


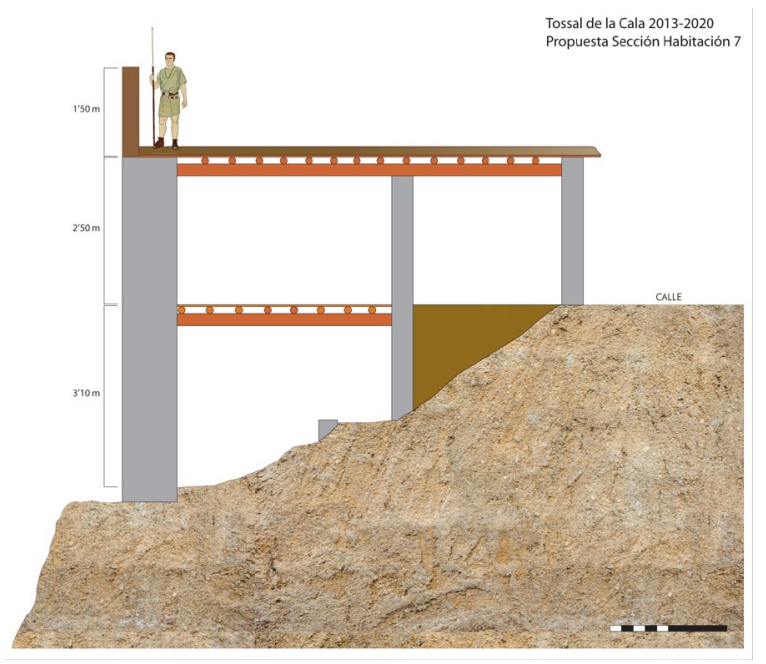

Figura 11. Recreación esquemática del alzado de la muralla a la altura del edificio 7 (elaboración propia).

9), confirmamos que presenta doble paramento de mampostería de labra y tamaño desigual, trabada con calzos y tierra, que no se dispone en hiladas horizontales; el paramento interior presenta bloques menores. El núcleo se rellena con una mezcla heterogénea de gravas, piedras y cerámica entremezclados con tierra oscura de traza arcillosa que recuerda un emplecton de aspecto tosco (Broconi, 2001). El paramento externo conserva una altura máxima de $0,91 \mathrm{~m}$, aunque en la mayor parte del trazado apenas subsisten las dos primeras hiladas. Respecto al grosor, tiende a concentrarse en torno a $1 \mathrm{~m}$, como vio Belda, aunque no existe una homogeneidad en su trazado, oscilando las medidas entre 0,83 y $1,03 \mathrm{~m}$ de valores extremos y resultando un valor medio de $0,94 \mathrm{~m}$. Dicho grosor medio no encaja mal dividido entre $0,296 \mathrm{~m}$, suponiendo así una anchura equivalente a tres pies romanos. En su trazado se identifican hasta dos giros, adaptándose a la topografía del escarpe rocoso a la altura de las habitaciones 7-8 y 15-16. En la estancia 17, se conserva un bloque dispuesto a tizón de $0,70 \mathrm{~m}$ de longitud, lo que permite intuir que la fortificación se levantó en sucesivos tramos o "cajas" que atestiguan, bien la secuencia constructiva, bien la obra de diferentes cuadrillas. Los trabajos de 2019 en el solar occidental han descubierto un nuevo bloque a tizón, por lo que tal vez se pueda hablar de una pauta constructiva (Fig. 10).

El zócalo de la muralla se levanta directamente sobre la roca; solo para salvar desniveles puntuales se extienden capas de tierra para asentar la primera hilada. A partir de una altura desconocida se levantaría un alzado cuya fábrica tampoco podemos concretar. Pudo ser de mampostería dada la fácil provisión de piedra, aunque parece más lógico pensar en una fábrica de ba- rro teniendo en cuenta que la obra exigía cierta rapidez en su ejecución. Belda menciona adobes al describir las construcciones, nunca para la muralla. En nuestras excavaciones hemos vuelto a documentar adobes sobre bancadas, mientras que la estructura de los estratos que colmatan las estancias es más propia de una fábrica de tapial. En cualquier caso, estamos ante una obra levantada con material local, primando la funcionalidad de un lienzo rápido de construir, adaptado a un terreno con fuertes pendientes que igualmente iba a determinar el urbanismo, siendo este un condicionante por encima de los principios de la teoría arquitectónica romana (Morillo, 2016, p. 14).

El sistema defensivo es tan sencillo como efectivo. Hablamos de una muralla de $1 \mathrm{~m}$ de grosor a la que intestan los muros medianeros de las estancias ${ }^{19}$ conformando un sólido bloque rectangular en el que los muros tienen una clara función estructural como tirantes; los escasos muros adosados al paramento defensivo compartimentan el espacio, probablemente en reformas posteriores. Esta pauta constructiva demuestra una indudable sabiduría técnica que busca la estabilidad del conjunto y requiere de un diseño previo para ir entrelazando y levantando al unísono muros y muralla. Así se configuran unas estancias bajas que pueden emplearse para cualquier tipo de actividad -almacenes, talleres, etc.-, y que en momentos críticos pueden rellenarse y conseguir un cuerpo macizo de mayor grosor, como en las murallas de casernas, cuyo concepto parece estar reproduciendo. Respecto a la altura, tomando como referencia el perfil del edificio 7, del que tenemos el desnivel real existente desde la calle hasta la muralla, y dando por supuesto que la cubierta de los edificios hacía la función de adarve, calculamos una altura del lienzo de unos $5 \mathrm{~m}$, a lo que añadimos un parapeto (Fig. 11). El trazado ligeramente retranqueado en la vertical del escarpe rocoso no deja espacio para torres o bastiones, por lo que, de existir, se dispusieron reforzando los accesos.

La topografía del cerro determina la ubicación de los accesos que, por el momento, no hemos localizado. Belda (1950-1951, p. 83) menciona en el extremo occidental "los restos de una calzada que por allí penetraba [...] recorriendo hacia el Sudoeste un breve pasillo flanqueado por duplicada muralla de empalme". Aunque nunca se podrá confirmar, pues este punto lo ocupa un edificio moderno, el declive de la topografía hacia ese sector hace suponer la existencia de un acceso, quizá de tipo poterna, pues quien entrara por

19 En la arquitectura ibérica la muralla también funciona como muro zaguero de las estancias, pero las paredes adosan siempre a la fortificación. 


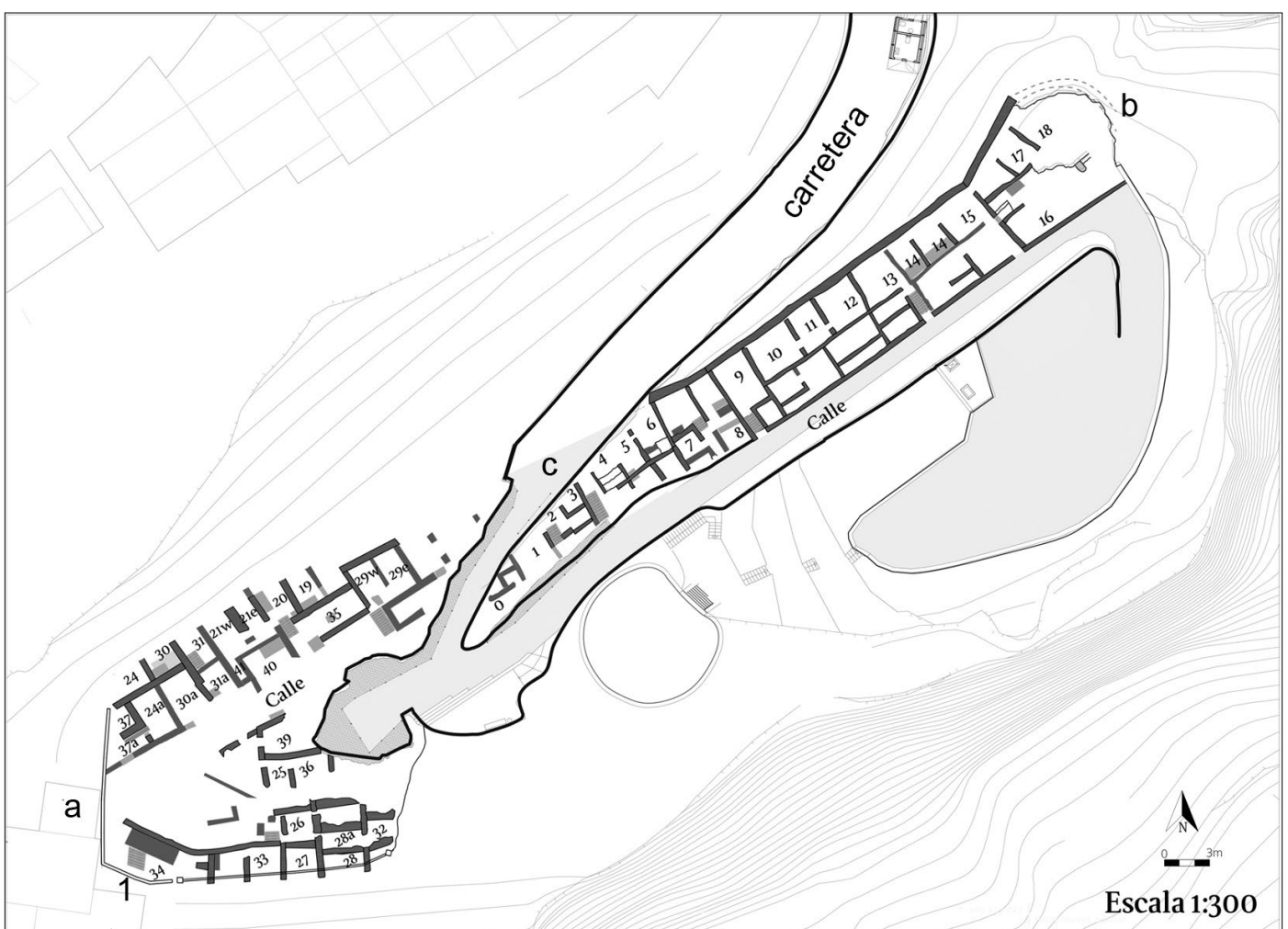

Figura 12. Planimetría general del yacimiento en la que se marcan los tres posibles accesos (a,b, c) y la ubicación de la estructura semiciclópea (1) (elaboración propia).

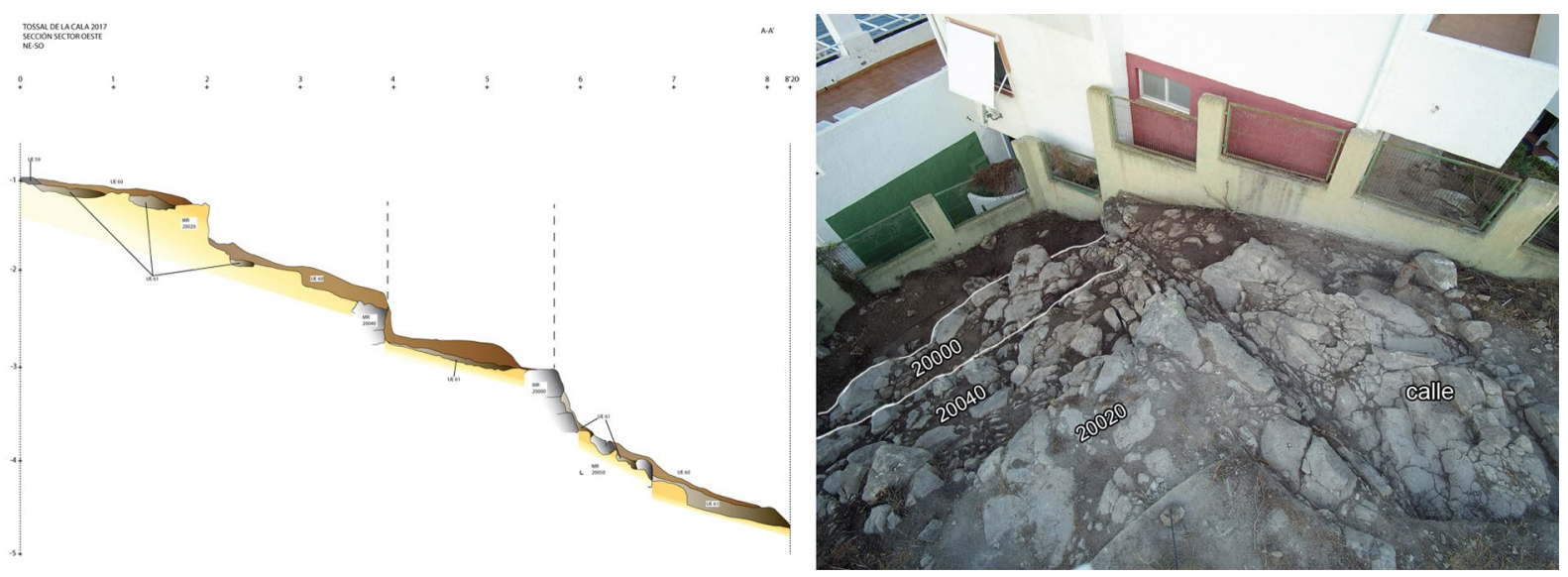

Figura 13. Estructura de fábrica semiciclópea situada cerca de la posible entrada occidental (fotografía propia).

aquí debía salvar el escarpe rocoso (Fig. 12, a). En esta zona localizamos una estructura que podría tener relación con el refuerzo defensivo de esa hipotética entrada (Fig. 12, 1). Junto al tramo de calle aledaño la roca natural ha sido forrada con grandes piedras configurando una superficie maciza de más de $5 \mathrm{~m}$ de ancho escalonada a dos alturas. Lo interesante de esta obra es que emplea un aparejo acorde a la II Manera del opus siliceum tipificado por Lugli (1957, pp. 73-75), muy habitual en las obras defensivas tardo-republicanas de la Hispania Citerior (Asensio, 2006, pp. 121-129) y que también hemos documentado en el Passet de Segària, empleado aquí como en la muralla de Norba (Quilici y Quilici, 2001, pp. 201-203, figs. 31, 33): con el aparejo ciclópeo se levantan terrazas sobre las que se construye la fortificación. Aquí, en cambio, podría responder a una construcción de desarrollo vertical de la que se conserva su base maciza (Fig. 13).

Otro lugar posible sería el extremo oriental y, así, los accesos al enclave se situarían en ambos límites de la calle que ordena el urbanismo (Fig. 12, b), aunque también en este punto la erosión y la carretera han de- 


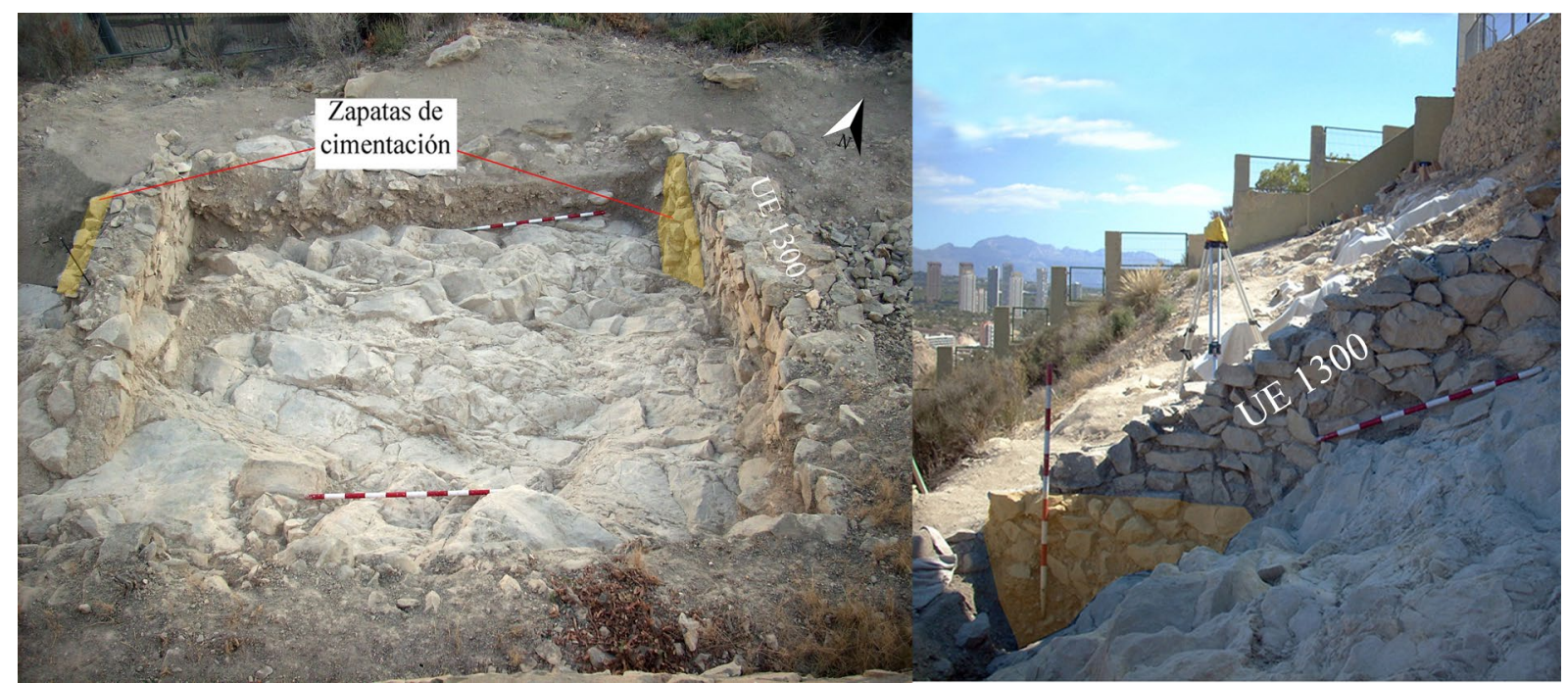

Figura14. Zapata estructural del muro medianero de la estancia 12 en el punto de unión con la muralla (fotografia propia).

jado al descubierto la roca natural sin estructuras. Una tercera opción nos la da la observación de las curvas de nivel en la vertiente norte. Pese a la fuerte inclinación, el ascenso es factible con un recorrido en zigzag que, de hecho, siguió la pala para abrir el camino en 1956. Por donde la máquina entró en el yacimiento se observa una discontinuidad del bloque constructivo septentrional que no descartamos pueda coincidir con el pasillo de una puerta de la fortificación que penetraría "recorriendo hacia el Sudoeste un breve pasillo flanqueado por duplicada muralla de empalme", como describió Belda, es decir, prolongando los lienzos que vienen del este y el oeste hasta superponerlos formando una puerta de corredor o de recubrimiento (Fig. 12, c). Esta tercera opción también será difícil de comprobar porque la pala arrasó todo hasta la roca.

\section{LA ARQUITECTURA}

Las construcciones se asientan hacia la cota de $92 \mathrm{~m}$ en su extremo oriental y descienden hasta $80 \mathrm{~m}$ en el occidental, en una distancia entre ambos puntos de algo más de $100 \mathrm{~m}$, de lo que se deduce una pendiente del $12 \%$ para el plano inclinado elegido para el asentamiento. Este desnivel habría originado un urbanismo irregular de tipo geomórfico característico de un asentamiento ibérico, y así lo vio Tarradell. Sin embargo, con un sencillo pero eficaz sistema de aterrazamientos, mediante paramentos de mampostería forrando los escalonamientos de la roca natural, se crearon plataformas sobre las que construir, un procedimiento inédito en la arquitectura ibérica contestana.

Belda describió las estancias construidas "con piedras no desbastadas y distribuidas sin orden que asentaban en barro común” (Belda, 1950-1951, p.
82). En efecto, los muros, de un grosor medio de 0,45 $\mathrm{m}$, se levantan con mampostería de tamaño mediano y pequeño trabada con tierra. No es una fábrica homogénea, advirtiéndose diferente disposición de los bloques que forman hiladas ocasionalmente. Asientan directamente sobre la roca o sobre una capa de regularización realizada con barro y ripio que, en ocasiones, podemos definir como una auténtica zapata estructural allí donde los muros intestan con la muralla (Fig. 14).

Los suelos eran "una capa de tierra superficial, sobrepuesta a otra relativamente muy gruesa, de pedrusca mezclada con polvo fino, quizá ceniciento, por cuyo medio nivelábase la natural escabrosidad de aquel suelo roqueño" (Belda, 1950-1951, p. 83). Es coincidente con el palmo cuadrado de pavimento que quedó milagrosamente intacto en la estancia 11: una superficie plana de tierra dura y apisonada de 1-2 cm de grosor $^{20}$ dispuesta sobre el depósito de regularización (Fig. 15). Define una capa idéntica, al menos en apariencia, a la encontrada en el yacimiento de Puig Castellar de Biosca (Lleida), aquí identificado como cocciopesto (Pera et al., 2016, p. 176; Pera et al., 2019, p. 28). Documentamos otros tipos de suelos, como la capa de arcilla anaranjada de 1-2 cm de grosor en la habitación 18 o un suelo de tierra grisácea-anaranjada muy dura, con trazas calizas y claramente apisonada, sobre un rudus de pequeñas gravas hallado en las estancias 31a, 32, 36 y 39, variedad que responde a los diferentes usos de los espacios. Como equipamientos Belda menciona bancos en casi todas las estancias, que nosotros no hemos documentado en tanto núme-

20 El grado de dureza obedece, sin duda, al añadido de un estabilizante que podría ser cal. Está en proceso de análisis. 


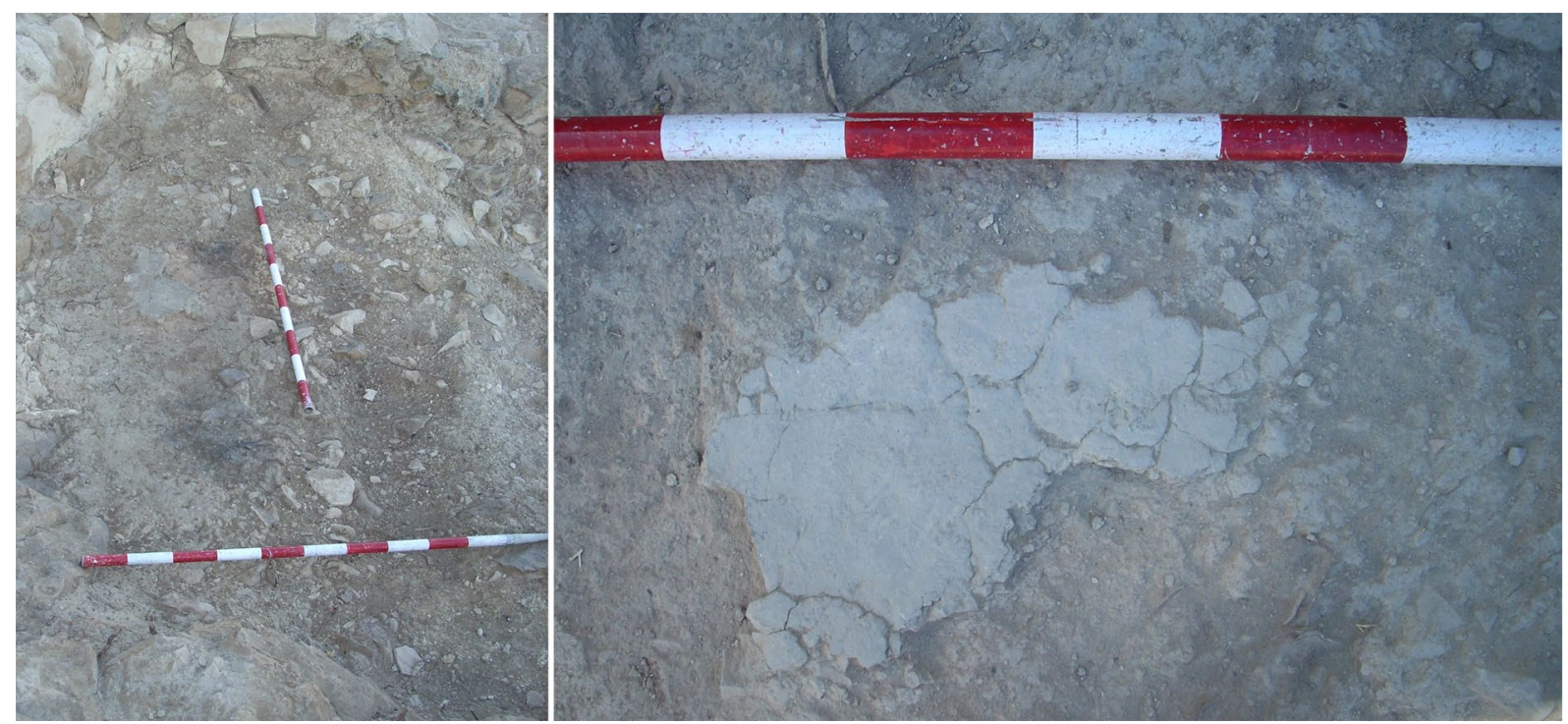

Figura 15. Restos del pavimento de la estancia 11 sobre la capa de regularización o rudus donde han quedado restos de hogueras (fotografia propia).

ro, así como las mencionadas escalerillas interiores de unos $0,85 \mathrm{~m}$ de luz. Identifica la techumbre en una capa de arcilla amarillenta caída sobre los pavimentos (Belda, 1950-1951, p. 83), luego podría tratarse de una cubierta hecha con manto de tierra sobre envigado.

Estas características definen las unidades constructivas que pasamos a describir. En la parcela oriental, atendiendo al juego de escaleras y vanos diferenciamos dos modelos constructivos. El primero está constituido por 2-3 espacios, uno a continuación del otro, generando una construcción estrecha y alargada a dos alturas, con apenas $3 \mathrm{~m}$ de luz por una profundidad total en torno a $7 \mathrm{~m}$, lo que da un espacio medio construido por bloque de unos $21 \mathrm{~m}^{2}$. Es el más generalizado y a él responden los bloques 3 a 9 y 13 (Fig. 12). A las habitaciones inferiores se accede desde la calle por estrechos pasillos provistos de escaleras realizadas con mampuestos grandes, marcando así los vanos en las fachadas, y dejan a un lado de su trazado la habitación superior. En su interior no existen otros equipamientos, salvo algún banco ocasional, y muy pocas presentan la roca recortada para nivelar la superficie de uso, como es el caso singular del bloque 7 (Fig. 16), siendo lo habitual cubrir el substrato rocoso mediante un depósito de tierra y ripio de hasta $1 \mathrm{~m}$ de espesor que adosa contra la muralla hasta alcanzar la cota de paso deseada.

No cabe duda de que las habitaciones a nivel de calle tuvieron un uso habitacional, mientras que las estancias bajas o sótanos se pudieron dedicar a usos tan dispares como almacenamiento o el espacio de descanso en los contubernia. Solo en una ocasión Belda se refiere como "Casa de los Plomos" a una de esas estancias pegadas a la muralla en el sector orien-

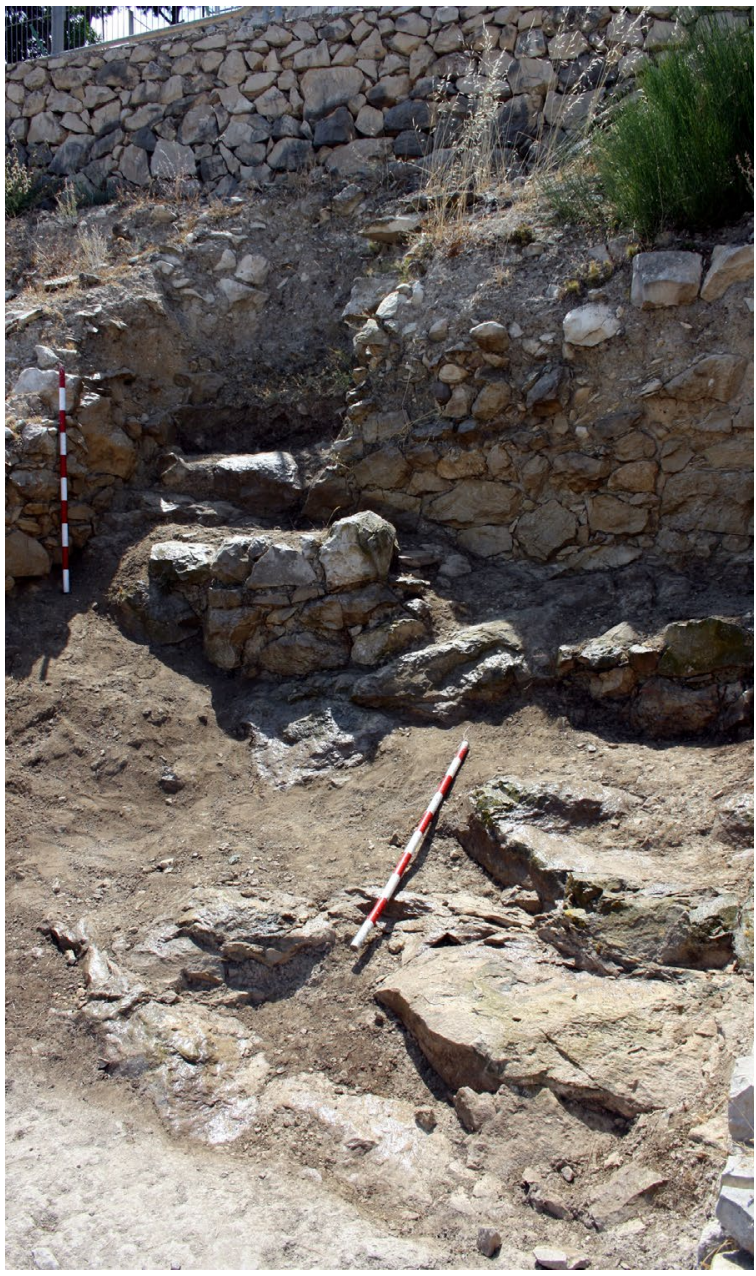

Figura 16. Imagen de la estancia baja del edificio 7 tomada al final de la campaña de 2013. Se observa el cubo de escalera y el arranque de la misma que conduce a la calle a una cota superior (fotografía propia). 


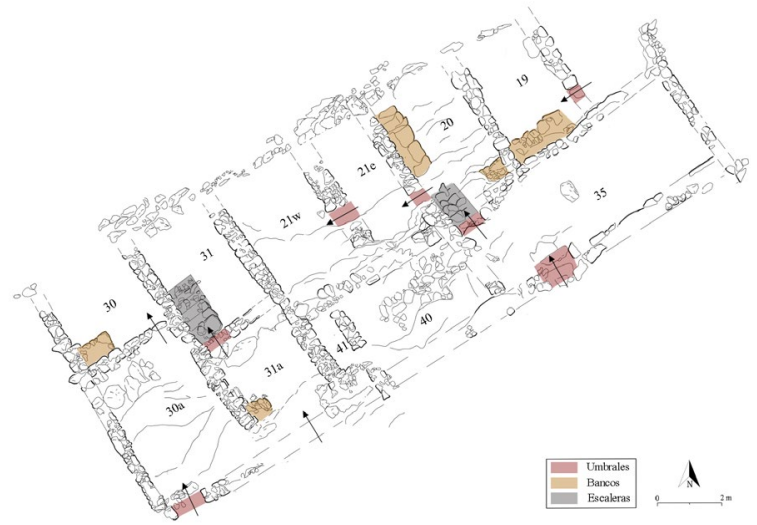

Figura 17. Detalle de algunas construcciones del sector occidental (elaboración propia)

tal, claramente un taller de trabajo por los abundantes restos de fundición que encuentra. Quedaría pendiente un análisis funcional detallado de las estancias, que abordaremos en un futuro estudio, aunque no será un objetivo fácil porque las excavaciones antiguas se llevaron por delante muchos datos relativos a los equipamientos interiores y contextos materiales in situ.

Un segundo modelo constructivo se establece en función de la circulación que implica la existencia de umbrales entre departamentos, imponiéndose en este caso una circulación paralela a la muralla. De acuerdo con ello, tendríamos dos edificios. El primero lo identificamos en las estancias bajas 10, 11 y 12, comunicadas mediante vanos de unos 0,80 m de luz. Estas estancias debían comunicarse con las correspondientes habitaciones altas y medias hoy desaparecidas. Ocupan una superficie construida de unos $54 \mathrm{~m}^{2}$, un tamaño estimable comparado con el primer modelo. El segundo edificio lo definen las estancias bajas 14, $15,16,17$ y 18 , conjunto que debe comunicarse con la calle a través de algún pasillo que hoy desconocemos, pues no hay constancia de escaleras (Fig. 12). Aquí los umbrales están pegados a la muralla, con una luz aproximada de $0,80 \mathrm{~m}$. El conjunto alcanza una superficie construida de unos $70 \mathrm{~m}^{2}$; salvo un gran banco adosado a la pared sur de las dos estancias 14, de uso desconocido, tampoco cuentan con equipamientos interiores que permitan discernir cuál pudo ser su función.

En la parcela occidental se observa una similar distinción, pues identificamos unidades constructivas perpendiculares a la muralla de menor tamaño, como los conjuntos 30 y 31 , junto a otras de mayor extensión y con planta en paralelo a la muralla, como los conjuntos 24-37 y 20-21-35 (Figs. 12 y 17). Del primer tipo constructivo, pondremos el ejemplo del edificio 31 , de nuevo con un departamento alto comunicado mediante escalera con su ámbito bajo, en un recorrido

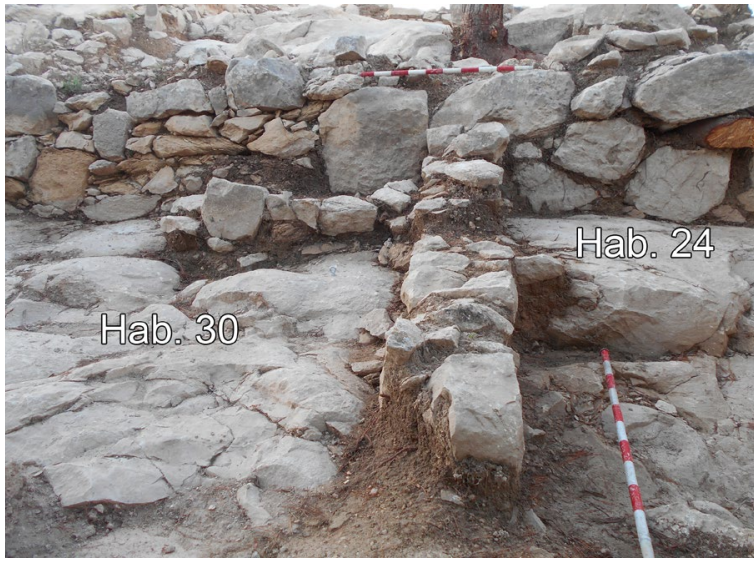

Figura 18. Banco rinconera de la estancia 30; por detrás el muro de aterrazamiento delimita las estancias 24 y 30 por el sur (fotografía propia)

que salva un desnivel de unos $3 \mathrm{~m}$. En estos edificios se documentan bancos o rinconeras, infraestructuras más comunes en este sector del enclave (Fig. 18) y sin duda asociadas a la función de estos espacios que, por el momento, no podemos definir. Las estancias bajas fueron cortadas por la valla perimetral de la parcela, por lo que no se puede concretar su superficie total, aunque parecen mantener unas dimensiones medias de $4 \times 3 \mathrm{~m}$ similares a las de la parcela oriental. Sí parece percibirse en este sector una mayor contundencia de las terrazas, algunas con un aparejo muy grande y alcanzando grosores superiores a los $0,60 \mathrm{~m}$.

El segundo tipo muestra un buen ejemplo en el conjunto de las estancias 20, 21 y 35 (Figs. 12 y 17). Desde la calle se accede a la estancia 35 , un espacio anómalo por sus dimensiones $(7,75 \times c a .4 \mathrm{~m})$ y casi $40 \mathrm{~m}^{2}$. El acceso se hace mediante un vano escalonado de $1,52 \mathrm{~m}$ de anchura abierto hacia el cuadrante suroccidental, lo que evidenciaría una puerta de doble hoja, la única documentada. Desde esta estancia superior se pasa mediante escalera de una luz de $0,83 \mathrm{~m}$ al cuerpo inferior del edificio compuesto por los departamentos 20, 21 este y 21 oeste, tres espacios estrechos y alargados pegados a la muralla y comunicados entre sí. El edificio, que alcanza casi $100 \mathrm{~m}^{2}$ de extensión, presenta una distribución extraña, pues la estancia 35 que funciona a modo de vestíbulo está claramente descentrada del resto.

Estos edificios abren a una calle que ya fue localizada en 1956 a la altura de la construcción 13 (Fig. 7), anotando que tenía 1,90 $\mathrm{m}$ de anchura y estaría "empedrada". Al redescubrir ese tramo en 2018 observamos una superficie prensada de tierra y guijarros del tipo viaglareastrata, con la que se rellenan las irregularidades de la roca natural para conseguir un plano transitable. Los trabajos de consolidación de 2020 la han exhumado en toda su extensión confirmándose como el vial que vertebra el asentamiento. En la parcela occidental 


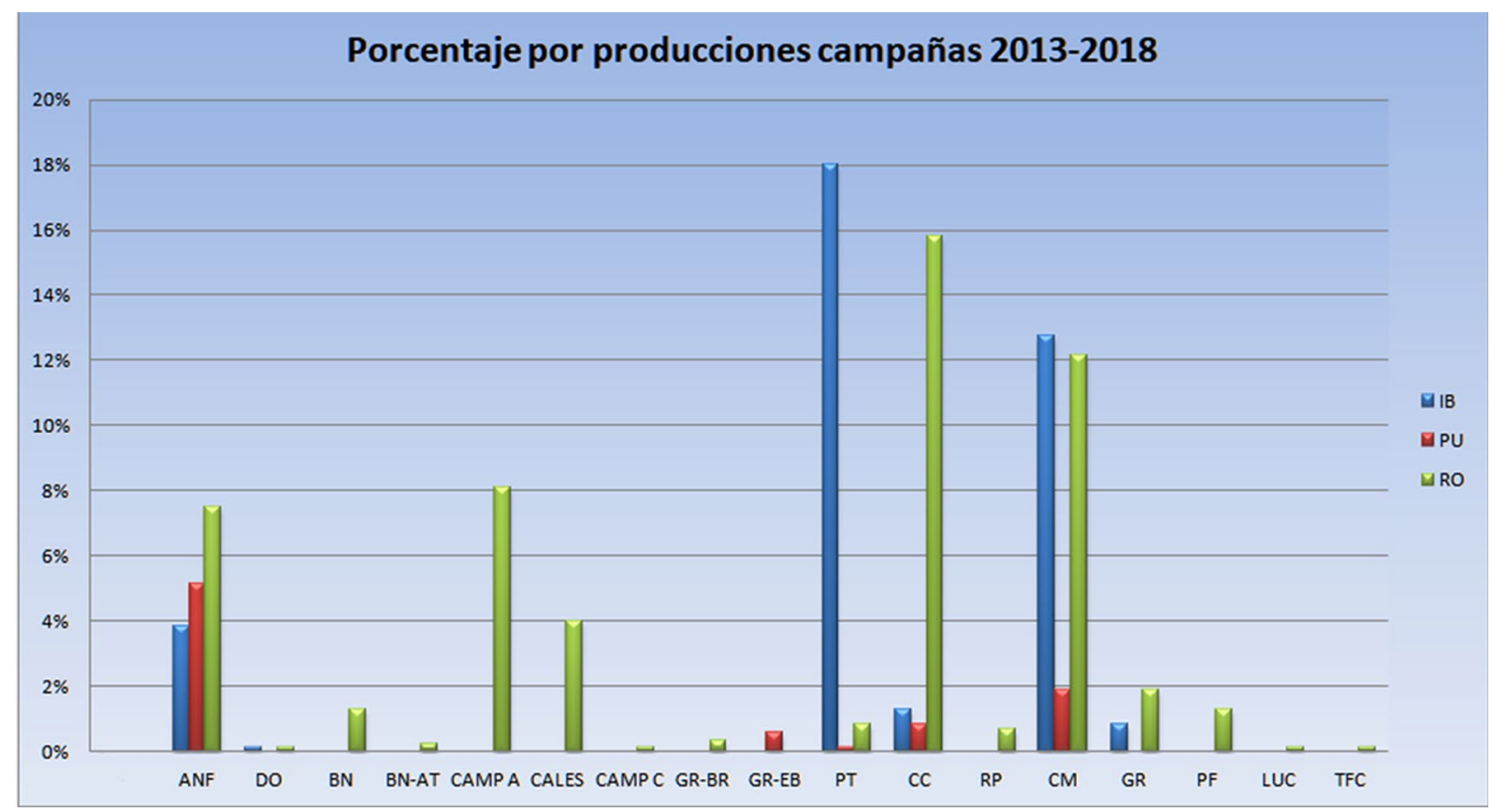

Figura 19. Gráfica de porcentajes por producciones (ANFora, DOlia, Barniz Negro, BN ATico, CAMPaniense A, CALES, CAMPaniense C, Gris Bruñida, Gris EBusitana, PinTada, CoCina, Rojo Pompeyano, CoMún, Gris, Paredes Finas, LUCernas, TFiChas) y procedencias (ibérica, romana y púnica) de los hallazgos cerámicos en el Tossal de la Cala (campañas 2013-2018) (elaboración propia).
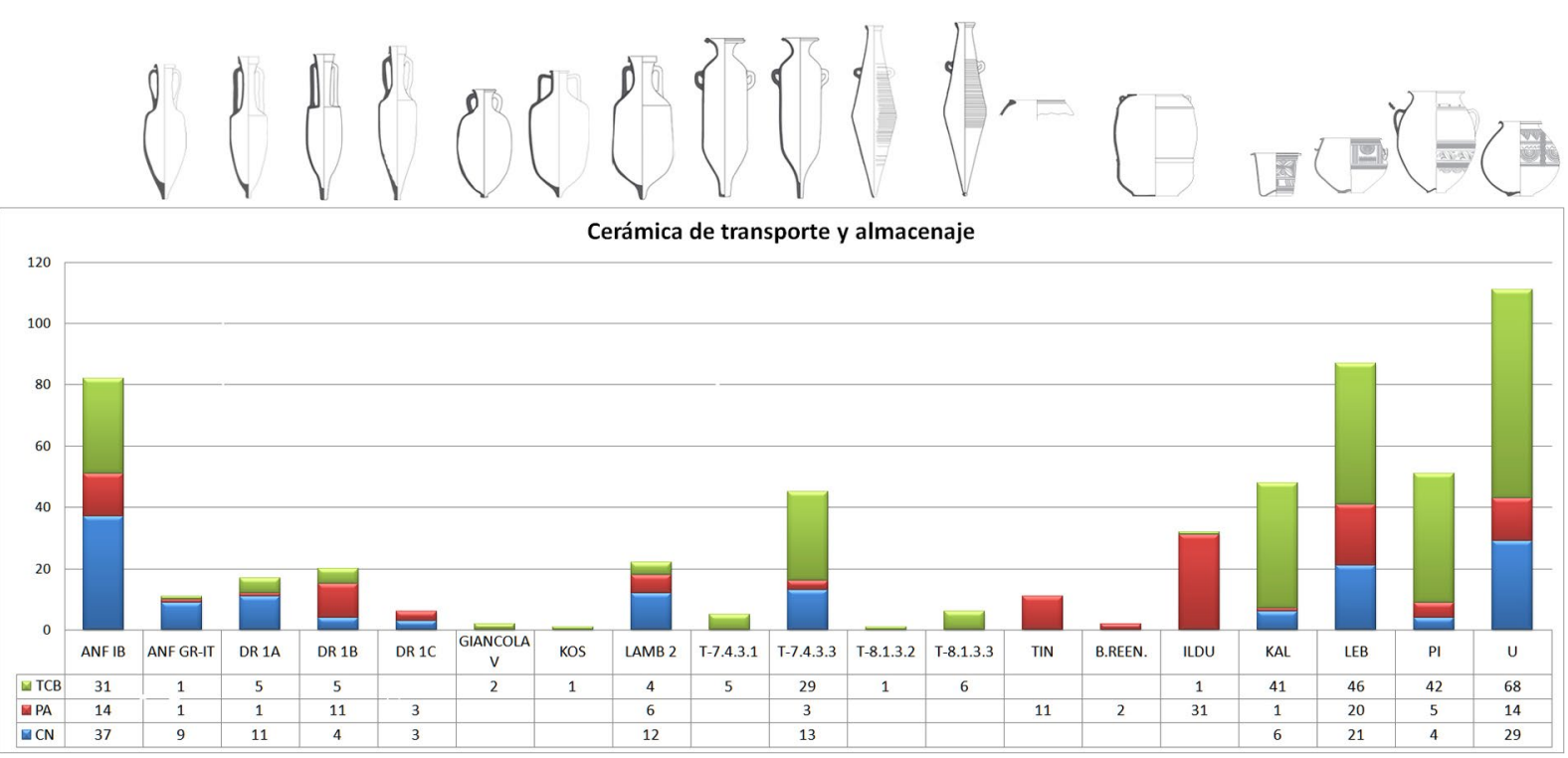

Figura 20. Vasos de transporte y almacenaje en Tossal de la Cala (verde), Penya de l’Àguila (rojo) y CapNegret (azul) (elaboración propia).

presenta una luz de $1,81 \mathrm{~m}$, ancho próximo al 1,90 del tramo oriental, teniendo en este punto una pendiente del $8 \%$. Aquí existen edificios extendiéndose por las vertientes norte y sur, pues la topografía lo permite, definiéndose un urbanismo organizado en calle central. Finalmente, la acusada inclinación del cuchillo rocoso en la cima apunta a un espacio poco urbanizado, aunque debió ser operativo, tal vez un área abierta en el punto de mejor visibilidad.

\section{EL CONJUNTO MUEBLE}

En su estudio sobre la cerámica ibérica pintada de la provincia de Alicante, S. Nordström (1969, pp. 66-67) destacaba que la cerámica romana en el Tossal de la Cala era "insignificante para poder hablar de un nivel romano republicano" y que era el enclave contestano con mayor variedad de estilos decorativos en sus cerá- 
micas. Por ello, cuando en la revisión de las excavaciones antiguas se documenta militaria romana pensamos en pequeñas guarniciones instaladas de forma temporal en los enclaves costeros, como ocurre en algunas áreas de Europa Central y Portugal. Sin embargo, la ocupación de enclaves por tropas romanas tiene lugar en una segunda fase de conquista, cuando es necesario reafirmar el control con una presencia permanente del ejército, y esta no parecía ser la situación de los yacimientos costeros alicantinos que se fundaban ex novo y se ocupaban por un tiempo muy concreto.

En esta idea encajaba que en las excavaciones de $1984^{21}$ la cerámica de procedencia no ibérica, con un $61 \%$, superara a la ibérica. Y aunque la cifra seguía siendo compatible con un poblado ibero dedicado al comercio, llamó nuestra atención que el porcentaje superara incluso el de la excavación de la plaza Cisneros de la Valentia sertoriana (Marín, Ribera y Serrano, 2004, p. 127), donde la cerámica ibérica representaba un $52 \%$ del total. Lo que finalmente cambió nuestra idea inicial fue comprobar que la cerámica de cocina era mayoritariamente itálica, mientras que la ibérica resultaba anecdótica, dato que se ha visto confirmado en nuestras excavaciones ${ }^{22}$ (Fig. 19). Finalmente, los repertorios por producciones mostraban que los vasos ibéricos predominantes no eran los de la vida cotidiana, sino recipientes de transporte -ánforas- y de almacenaje de capacidad media, como tinajas, tinajillas, kalathoi o lebetes (Fig. 20), presentes también en la Valentia sertoriana.

En nuestros trabajos en el Tossal de la Cala, el hallazgo de ánfora campana es constante, tanto que, conociendo los problemas de aprovisionamiento del ejército sertoriano, como también del pompeyano, valorar esa alta presencia tiene interés (Fig. 20). Destaca el vino itálico campano -Dr. 1 (A y B)-seguido del apulo -Lamb. $2-\mathrm{y}$, por su rareza, mencionamos un ánfora de Cos que contenía un vino salado de larga maduración, muy apreciado en ambientes militares (Tchernia, 1986, p. 19) y al que Plinio atribuía propiedades medicinales (Nat. Hist., XIV, 77-79). El pescado en salazón transportado desde el Estrecho de Gibraltar debió ser un alimento frecuente por la abundancia de ánforas T-7.4.3.1 y T-7.4.3.3 (Ramón, 1995,pp. 210, 212; 2008,p. 81; Bayo, 2018,pp. 461-500). En cambio, el aceite proveniente de Bríndisi llega poco, como podemos deducir de solo dos asas con sendos sellos VISELLI ${ }^{23}$ y C. ANNIO (Manacorda,

21 Un total de 1546 registros de los que 1446 son piezas cerámicas y 902 NMI.

2214.657 registros de las campañas de 2013 a 2018 .

23 El sello VISELLI sobre asa de ánfora brindisa también está presente en los niveles sertorianos de Valentia (Ribera y Marín, 2004-2005, p. 276).
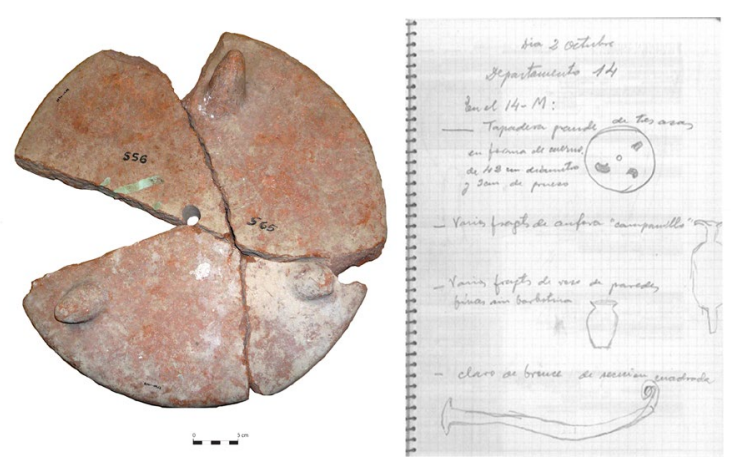

Figura 21. Tapadera de dolium de las excavaciones de 1956 y página del diario de Ramos donde se registra el hallazgo (fotografía Archivo Histórico Municipal de Benidorm).

1994, p. 5; Desy, 1989). Podrían pertenecer a ánforas del tipo Giancola 5 (Apani V) que transportan un aceite muy apreciado por algunas élites romanas en este momento (Carreras et al., 2016, p. 110; Bayo, 2018, pp. $368,480-484)$. El aceite formaba parte fundamental de la dieta de los soldados, aunque por el número de ánforas olearias está claro que el aceite brindisino no lo sería, quizá sí de los mandos. Por su valor, es improbable que se usara para iluminación. Las tres lucernas -tipos Ricci G, Dressel 1b y Dressel 2- halladas en el Tossal de la Cala (Ricci, 1974, p. 204; Morillo, 2015, p. 346; Bayo, 2018, pp. 607-608), que asociamos a los stili de hueso y bronce en el ambiente de un scriba, se pueden alimentar con grasas y aceites pobres. En cambio, un aceite de calidad se usa en la elaboración de unguenta y otros remedios que podían ser aplicados con la sonda espatulada o spathomele (Milne, 1970, pp. 55, 58-60) aparecida en las excavaciones antiguas, similar a otras de Cáceres el Viejo (Ulbert, 1984, tafel 20.126-128).

Volviendo a los recipientes de almacenaje, es la primera vez que se constatan dolia romanas y tinajas tipo Ilduratin en un yacimiento alicantino (Burillo, 1980, p. 222; Burillo, Cano y Saiz, 2008, p. 176; Saiz y López, 2011, p. 268) (Fig. 20). Puesto que el dolium solía taparse con una pieza de madera (Salido, 2017 , p. 242), damos a conocer una gran tapadera cerámica de $45 \mathrm{~cm}$ de diámetro y tres mamelones como asideros hallada en 1956 (Fig. 21). Las tinajas Ilduratin podrían portar cereal o vino desde el área celtibérica (Burillo, 2009, p. 334; Bayo, 2018, pp. 500-504). Su presencia, en cualquier caso, además de señalar posibles vías de avituallamiento, indica que los habitantes del Tossal de la Cala no producían sus recursos alimenticios.

La investigación actual entiende la comensalidad como un medio para identificar un grupo social a través de sus costumbres gastronómicas y, en efecto, 


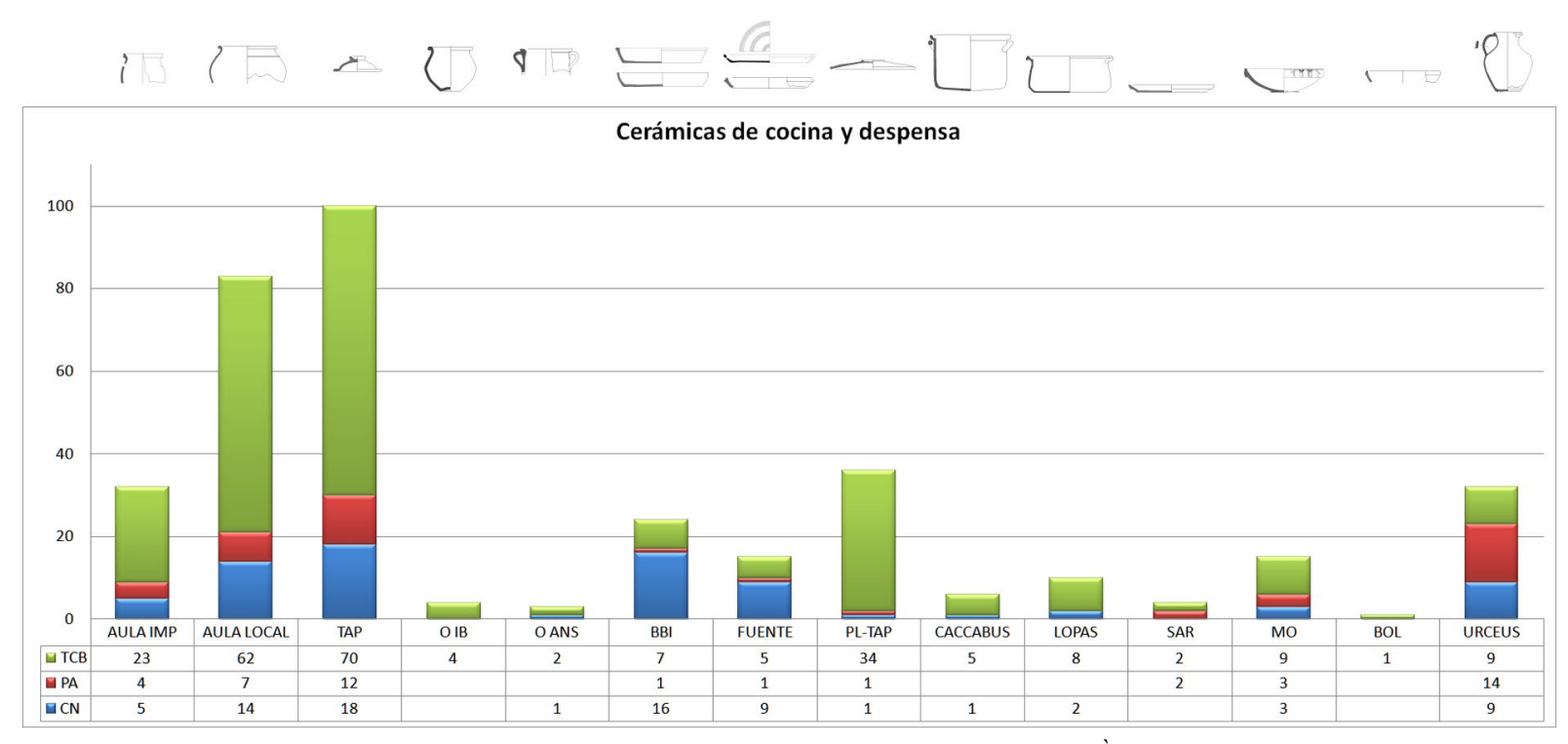

Figura 22. Vasos de cocina y despensa romanos entre Tossal de la Cala (verde), Penya de l'Àguila (rojo) y CapNegret (azul) (elaboración propia).

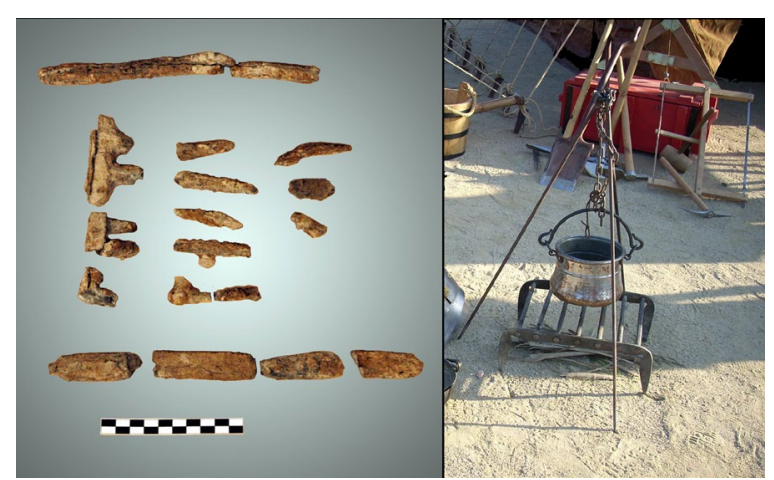

Figura 23. Fragmentos de la parrilla hallada en las excavaciones de 1984 y recreación de Tarraco Viva (fotografía propia).

tanto la elaboración de los alimentos como la forma de consumirlos forman parte del bagaje cultural de cada sociedad. El elemento clave para el conocimiento de las costumbres gastronómicas es, sin duda, la cerámica de cocina. Sabiendo que en el Tossal de la Cala las ollas ibéricas son prácticamente inexistentes, describir la vajilla de cocina romana respecto al tipo de comida que se cocinaba en cada recipiente ofrece otra perspectiva. El repertorio de la Figura 22 muestra que los habitantes del Tossal de la Cala seguían una dieta sencilla compuesta básicamente de harina -el puls- cocinada en las aulae (Roth, 1999, p. 45; Beltrán, 2002, p. 205; Olcese, 2003, p. 38), completada con guisos a base de legumbres, carnes y/o pescado como minutalia (Bats, 1988, pp. 46, 69; Bayo, 2018, p. 520) o la patina, cocinados en cazue- las tipo patinae, caccabi, lopades y sartagines (Beltrán, 2002, p. 206; Lejavitzer, 2005, p. 150; Huguet, 2013, p. 311 $)^{24}$. En nuestras excavaciones encontramos jibias de sepia, lapas y pequeños caracoles de mar de la especieTegula tridentata, lo que confirma que una de las tareas cotidianas fue el aporte de pesca fresca para el consumo diario (App. Iber. 54; Roth, 1999, p. 31). La dieta se completaría con salazón de pescado, vino y aceite que, como hemos visto, procedía de diferentes puntos del Mediterráneo central y occidental. En la cocina romana las ollas y cazuelas se solían colocar alejadas de las brasas para que la cocción fuese lenta y constante, utilizando para ello una parrilla (Bayo, 2018, p. 533). La localizada en la estancia 14 del Tossal de la Cala (Fig. 23) es similar a las de Libisosa, la Caridad ${ }^{25}$ y los campamentos de Alesia y Arras (Uroz, 2012, p. 281, fig. 220; Brouquier-Reddé y Deyber, 2003, pl. 96.167; Jacques y Prilaux, 2008, p. 60, fig. 1.1.7).

Por último, la vajilla fina se compone en un $1,90 \%$ por vasos de paredes finas tipos Mayet II y III y por campaniense A $(7,67 \%$ del total) y calena $(4,33 \%$ del total). La campaniense A predomina sobre la calena tanto en porcentaje como en variedad

24 Para más información sobre tipos, producciones y procedencias de la vajilla de cocina y servicio de despensa remitimos a la tesis doctoral de S. Bayo (2018). Es de especial interés la identificación de una producción de aulae de ámbito local o regional presente también en la Valentia sertoriana (Huguet, 2013, p. 418 ss.).

25 Ceres.mcu.es: red digital de museos de España, n. ${ }^{o}$ inv. 15780, 15805 y 16266. 

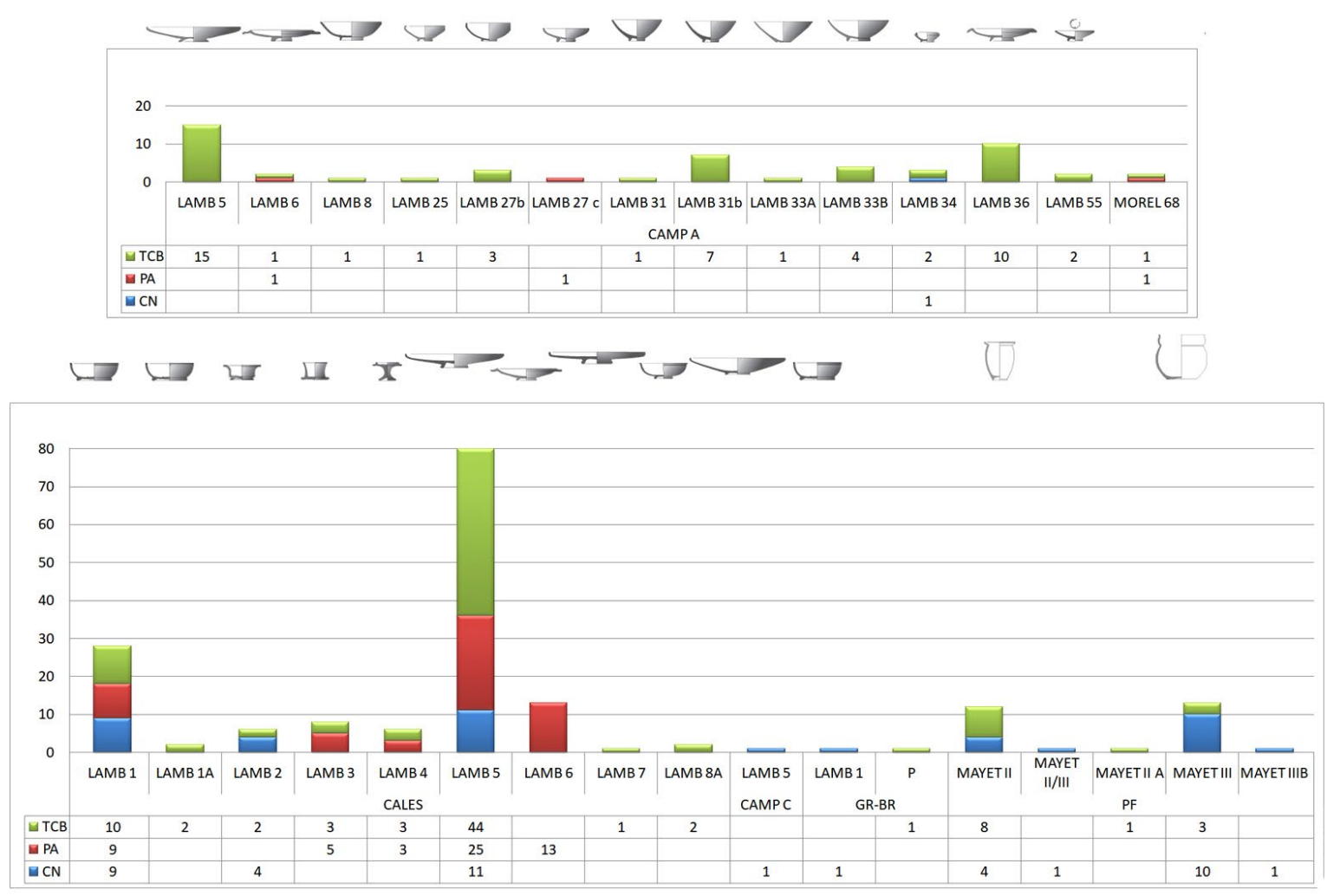

Figura 24. Vajilla fina de barniz negro y paredes finas entre Tossal de la Cala (verde), Penya de l’Àguila (rojo) y CapNegret (azul) (elaboración propia).

de vasos, como puede observarse en el gráfico de la Figura 24 (Bayo, 2018, pp. 545-549) ${ }^{26}$.

Respecto al armamento, de las excavaciones de 1943 procede un fragmento de moharra de pilum de lengüeta tipo Šmihel (Connolly, 1997, p. 44; Quesada, 2007, p. 382; Bayo, 2010, p. 127; 2018, pp. 573-574) (Fig. 25, 1). Mientras que entre los soldados iberos es común el pilum de cubo (Quesada, 2007, p. 384), el de lengüeta se encuentra en Numancia (Luik, 2002, abb. 181) y es frecuente en ambientes militares tardo-republicanos sertorianos (Ribera, 1998, p. 167), como La Caridad (Vicente, Punter y Ezquerra, 1997, pp. 183184; Quesada, 2007, fig. 2) o Cáceres el Viejo (Ulbert, 1984, tafel. 24.187-194 y 25). De las excavaciones de 1943 también proceden dos regatones de lanza y un fragmento de empuñadura de un pugio (Bayo, 2018, p. 577), un arma adicional común entre los celtiberos que fue ganando popularidad dentro del ejército ro-

26 En la Figura 23 la suma de vasos por tipos arroja valores mayores para la cerámica calena, lo que puede confundir si se compara el dato con los porcentajes por producciones de la Figura 19, donde la campaniense A casi duplica a la calena. Ello se debe a la fragmentación de los vasos de campaniense A, que no siempre permite identificar la forma tipológica pero sí contabilizar como individuo distinto. mano hasta convertirse en un elemento imprescindible (Goldsworthy, 2003, p. 30) (Fig. 25, 2-3). En el probable taller denominado "Casa de los Plomos", Belda localizó una plancha de plomo de $70 \mathrm{~cm}$ de diámetro, abundantes restos de fundición, varios glandes y unas pesas de red de pesca (Belda, 1950-1951, p. 88), y en nuestras intervenciones han aparecido dos glandes de 54 gr (1 sextans). Por último, unas tachuelas de bronce de cabeza plana podrían formar parte de un scutum semicilíndrico propio de la infantería pesada (Fig. 25, 6), como hemos visto en Ambrussum (Dedet, 2012, fig. 96E; Quesada et al., 2015, p. 388).

Otros objetos evocan la vida cotidiana. Una sierra a dos manos de 1,80 m de longitud (Belda, 1950-1951, p. 98; Bayo, 2018, p. 595), un cincel y una azuela son herramientas para el trabajo de la madera (Fig. 25, 9, 4, 7). La azuela sirve para carpintería de ribera y para dar forma a muebles, puertas o pilares para la construcción, como se puede ver en la columna de Trajano (Ulrich, 2007, pp. 16-19). Con estos trabajos cabe relacionar además clavos de hierro y bronce y tachuelas hallados por J. Belda en 1943 (Fig. 25, 8) y en nuestras excavaciones, todos con vástago de sección cuadrangular y cabeza cónica o plana (Bayo, 2010, p. 118). La presencia de una plomada se debe relacionar con la construcción del fortín (Fig. 25, 5). Los ponderales de bronce y de 


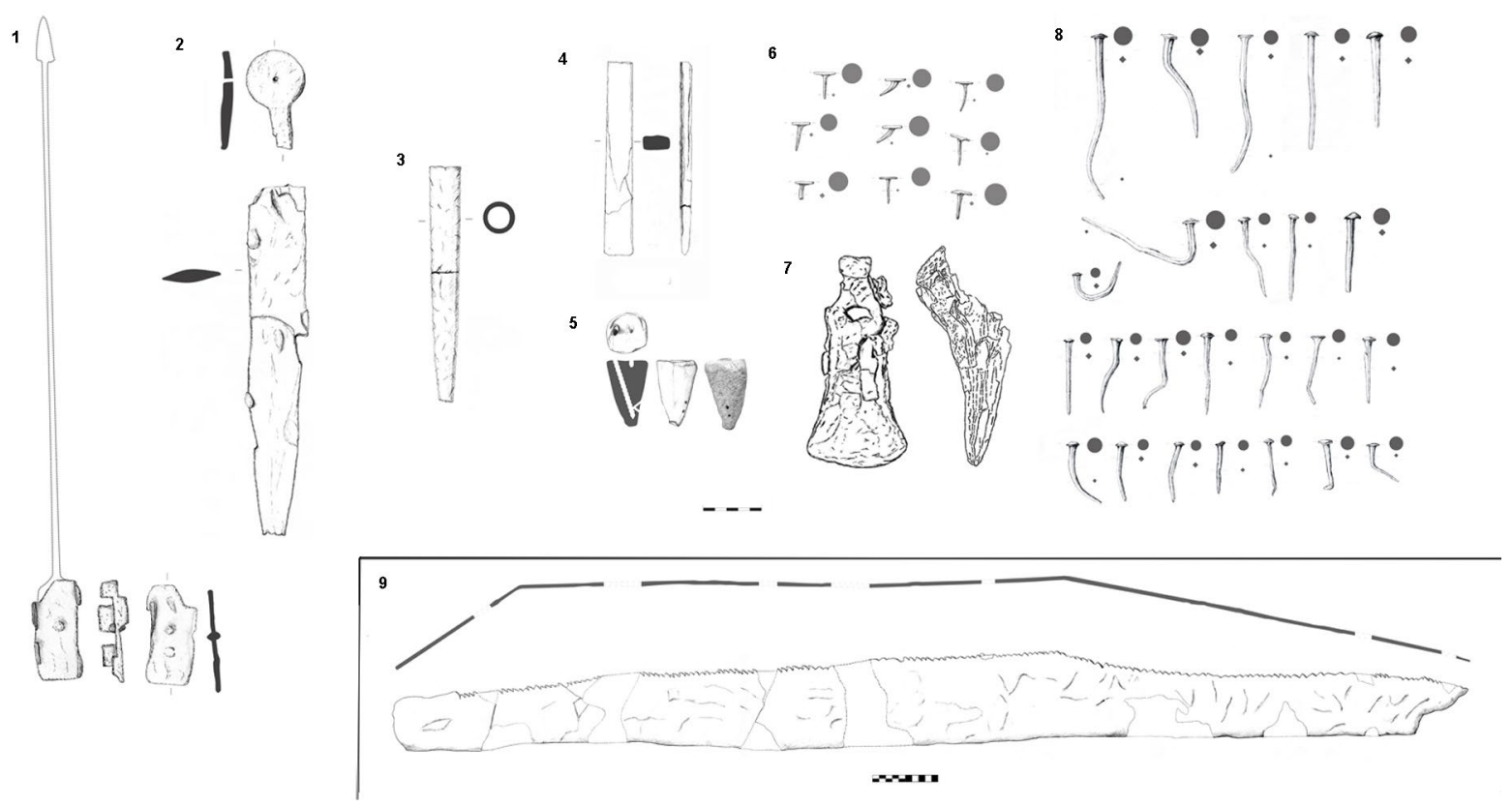

Figura 25. Conjunto de militaria recogido en las intervenciones de 1943, 1984 y 2016: 1. Moharra pilum Šmihel, 2. Pugio, 3. Regatón lanza, 4. Cincel, 5. Plomada, 6. Tachuelas, 7. Azuela, 8. Clavos, 9. Sierra (elaboración propia).
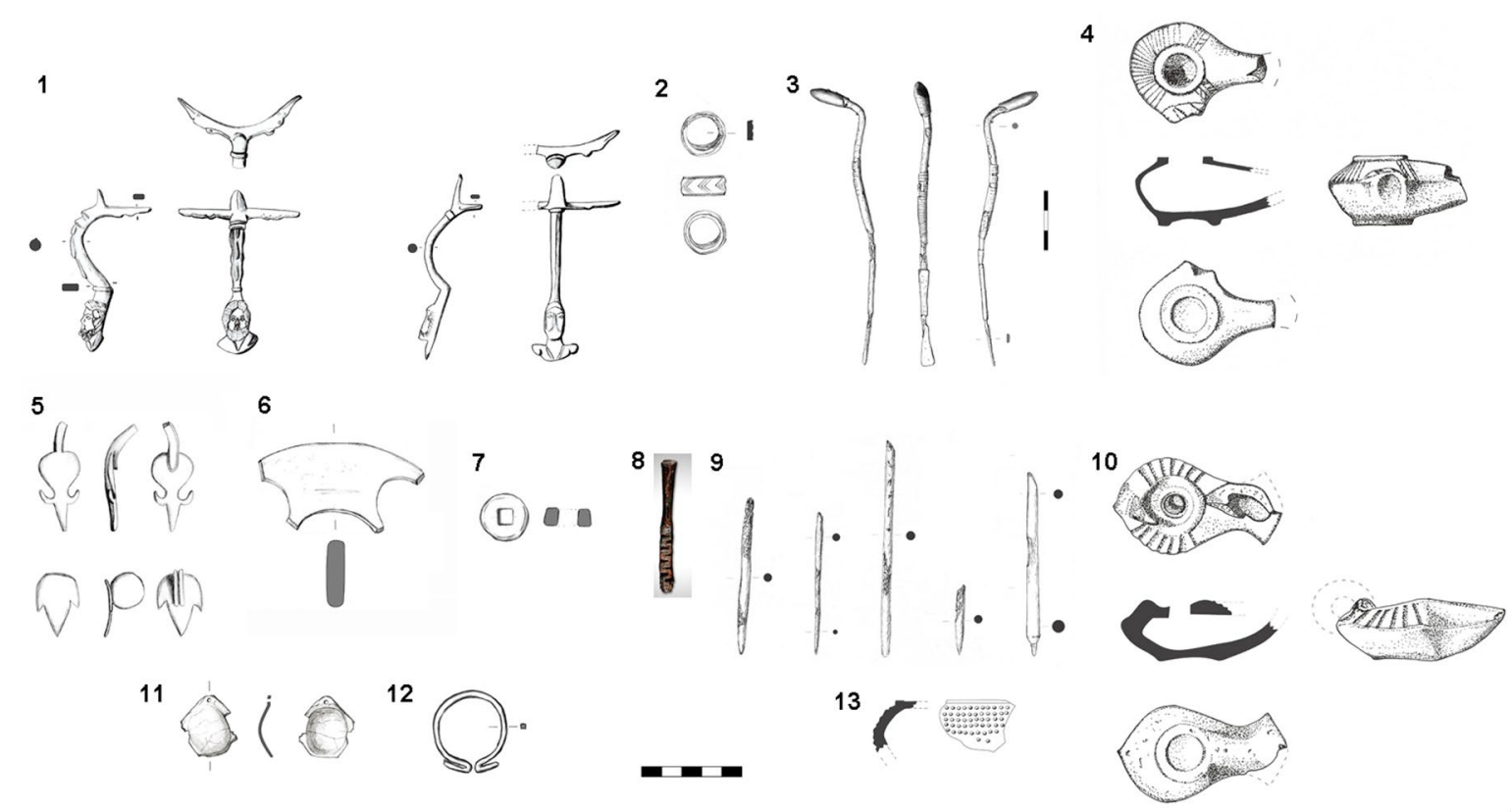

Figura 26. Conjunto de objetos de metal y lucernas cerámicas recogidoen las intervenciones de 1943 y 1984: 1. Asas Piatra Neamt, 2. Anillo de hueso, 3. Spathomele, 4. Lucerna Dr. 1b, 5. Asas Gallarate, 6. Pie de sítula, 7. Ponderal, 8. Stilus bronce, 9. Stili hueso, 10. Lucerna Ricci G, 11. Bulla, 12. Fíbula en omega, 13. Lucerna Dr. 2 (elaboración propia).

plomo son imprescindibles para controlar pesos y medidas (Fig. 26, 7), cometido del administrador de las raciones entre los soldados o del médico al que perteneció la sonda espatulada. Un asa del tipo Gallarate y dos Piatra Neamt señalan la existencia de las jarras de forma bitroncocónica (Boube, 1991, p. 24) que suelen ir acompañadas de coladores para el consumo de vino por parte de la oficialidad del ejército (Mansel, 2004, pp. 25, 27) (Fig. 26, 1, 5). El repertorio de vajilla de bronce se completa con una sítula que identificamos partir de un pie (Bolla, Boube y Guillaumet, 1991; Erice, 2007, p. 203) (Fig. 25, 6). En relación con el servicio de mesa de los oficiales hay un par de cuencos de vidrio prensado con decoración reticulada que reconocemos a partir 


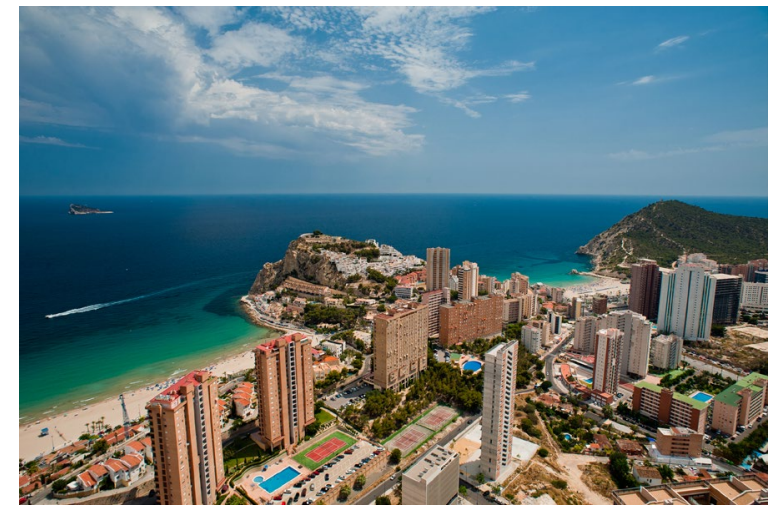

Figura 27. El Tossal de la Cala visto desde la azotea del hotel Bali, donde se aprecian las excelentes condiciones naturales como fondeadero (fotografía D. Martínez).

de sendos fragmentos (Price, 1981, pp. 100, 102; Bayo 2010, fig. 78). A la indumentaria personal del soldado asociamos un curioso anillo de hueso con decoración en espiga (Fig. 26, 2), cuyo paralelo más cercano está en la fosa votiva de Libisosa (Uroz 2012, p. 167), y una fíbula en omega del tipo 21.2.b3 de Mariné (2001, p. 272) (Fig. 26, 12). Por último, cabe destacar una plaquita de bronce ovalada con varias perforaciones que identificamos como bulla ${ }^{27}$ (Bayo 2010, pp. 122-124) (Fig. 26, 11).

\section{LA REINTERPRETACIÓN ARQUITECTÓNICA Y FUNCIONAL: UN FORTÍN ROMANO REPUBLICANO EN LA COSTA CONTESTANA}

Los trabajos en el Tossal de la Cala a partir de 2013 permiten descartar la visión tradicional del oppidum ibérico costero. Sin duda, estamos ante un asentamiento fortificado en altura, con un magnífico control sobre el espacio marítimo y el territorio inmediato. Sus flancos septentrional y occidental, los únicos accesibles, fueron protegidos con una fortificación adaptada a la topografía, aprovechando una cresta caliza que desciende de este a oeste (Fig. 27). La fábrica de la muralla es sencilla, un lienzo de mampostería de escaso grosor; lo novedoso fue "coser" los muros de las estancias al lienzo, de forma que funcionase como gran muro de contención atirantado. Así se solucionan las tensiones estructurales derivadas de construir sobre un fuerte desnivel y, además, muralla y estancias se funden en un bloque constructivo que recuerda las murallas de casernas de raigambre helenística,

27 La bulla se vincula a niños o jóvenes, aunque empiezan a hallarse en ambiente militar, como la batalla de Baecula de la segunda guerra púnica (Bellón et al., 2015, p. 597). con todas las ventajas operativas y espaciales que este sistema proporciona. Dicho desnivel justifica la altura de la fortificación que, según hemos visto, alcanzaría unos $5 \mathrm{~m}$ hasta el camino de ronda. En buena parte del alzado emplearía una fábrica de barro, que contribuía a aligerar la obra y a reducir el coste y tiempo empleados en su edificación y que están perfectamente constatadas para sistemas defensivos complejos, tanto en la arquitectura helenística (Adam, 1982, pp. 19-20) como en la romana republicana.

El urbanismo lo vertebra una única calle que desciende en dirección oeste, a cuyos lados se disponen sendos bloques constructivos divididos en unidades modulares alineadas en batería. El septentrional, de mayor extensión y mejor conservado, recuerda los modelos arquitectónicos de los barracones de tropa (centuriae) dispuestos per strigas, edificios alargados con pórticos subdivididos a su vez en contubernia de dos estancias (arma y papilio). El acusado desnivel del terreno en el Tossal de la Cala condiciona la distribución de las construcciones, aprovechando la pendiente para crear estancias a dos alturas por detrás del muro de fortificación. A las inferiores a manera de sótanos se accede mediante escaleras de obra. Las superiores, situadas ya a nivel de calle, se articularían sobre las estructuras subyacentes, repitiendo la misma compartimentación modular, pero necesariamente construidas en una fábrica de barro más ligera. Así pues, suponemos que las estancias para la vida cotidiana del fortín serían las superiores, de las que solo nos ha quedado la inmediata a la calle.

Otro aspecto en el que merece la pena detenerse es el de la modulación arquitectónica del conjunto, netamente romana en cuanto al módulo empleado, el pes monetalis $(0,296 \mathrm{~m})$. El ancho de los muros medianeros, unos $0,45 \mathrm{~m}$, un pie y medio, es justamente la mitad que la muralla $(0,94 \mathrm{~m})$. Por el contrario, el ancho de la calle multiplica por dos a la muralla, resultando ser de 1,90 m (6 pies). Respecto al tamaño de las habitaciones, en líneas generales tendríamos una modulación de $12,5 \times 9$ pies -al menos es la medida más repetida- $(3,70 \times 2,65 \mathrm{~m})$ (Tab. 1$)$, y los umbrales y escaleras se acercan a un módulo de dos pies y medio de anchura (0,75-0,80 m). Estos cálculos confirman que la metrología empleada deriva de un sistema de medidas específicamente romano ${ }^{28}$.

28 Aunque las medidas se han calculado sobre el pes monetalis, tenemos en curso un análisis más detallado de las dimensiones y la modulación para establecer si el patrón metrológico fue dicha medida o el pes italicus o pes oscus de $0,275 \mathrm{~m}$. 


\begin{tabular}{|c|c|c|}
\hline Habitaciones & Profundidad & Luz \\
\hline 2 & $1,25 \mathrm{M}$ & 1,57 \\
\hline 3 & $1,75 \mathrm{M}$ & 1,97 \\
\hline 4 & $2,17 \mathrm{M}$ & 3,55 \\
\hline 5 & $3,85 \mathrm{M}$ & 2,39 \\
\hline 6 & 3,36 & 2,65 \\
\hline 7 & 3,81 & 3,15 \\
\hline 8 & 3,45 & 2,30 \\
\hline 9 & 5,25 & 3,33 \\
\hline 10 & 3,87 & 4,30 \\
\hline 11 & 3,88 & 2,60 \\
\hline 12 & 3,94 & 3,66 \\
\hline 13 & 3,99 & 3,65 \\
\hline 14 & 3,88 & 2,05 \\
\hline $14 \mathrm{~B}$ & 3,90 & 2,70 \\
\hline 15 & 4,02 & 3,42 \\
\hline 16 & 3,30 & 2,89 \\
\hline 17 & 4,03 & 2,83 \\
\hline 19 & $3,51 \mathrm{M}$ & 2,46 \\
\hline 20 & 3,68 & 2,68 \\
\hline $21 \mathrm{E}$ & $3,86 \mathrm{M}$ & 1,76 \\
\hline $21 \mathrm{~W}$ & $3,46 \mathrm{M}$ & 2,56 \\
\hline 24 & $2,45 \mathrm{M}$ & $3,44 \mathrm{M}$ \\
\hline 31 & $3,20 \mathrm{M}$ & 2,47 \\
\hline $29 \mathrm{E}$ & 2,85 & 2,28 \\
\hline $29 \mathrm{~W}$ & 2,94 & 2,32 \\
\hline 30 & $2,15 \mathrm{M}$ & 2,96 \\
\hline 42 & 3,09 & 2,85 \\
\hline
\end{tabular}

Tabla 1. Medidas de las estancias bajas de la ladera norte mejor definidas. M: medida mínima al estar la estancia parcialmente destruida. Mediana: 3,71 (12,5 pies) × 2,64 (9 pies) (elaboración propia).

A pesar de que la evidencia material, ampliada significativamente en las últimas dos décadas, muestra una gran variabilidad en morfología y sistemas edilicios aplicados a recintos militares, consecuencia de la propia evolución de la técnica de castrametación romana y de la adaptación a circunstancias concretas (Morillo 2014, 2016, pp. 16-29), nos podría parecer que el esquema constructivo del Tossal de la Cala se aleja de los modelos canónicos de asentamientos militares romano-republicanos. Sin embargo, murallas de aproximadamente $1 \mathrm{~m}$ de ancho, edificadas con distintas técnicas constructivas, se constatan ya en la arquitectura helenística de fortines menores, como Kydna, en Licia, o Phylia, en Vrachos (Adam, 1982, pp. 123-165; Hellmann 2010, pp. 397-353). En este último existe incluso una estructura interior alargada con construcciones idénticas en batería que recuerda la estructura de los barracones romanos. Este hecho nos pone ante la existencia de diferentes modelos de fortificación de raigambre helenística empleados selectivamente por Roma durante el periodo tardo-republicano. El desconocimiento de los modelos de fortines y fortalezas contemporáneas no urbanas en la propia Italia nos priva por el momento de una base de comparación inestimable, a pesar de que los datos que vamos conociendo apuntan hacia modelos que no se apartan mucho de los aquí presentados (Cera y Quilici Gigli, 2001).

Otro elemento que nos retrotrae a las influencias helenísticas mediterráneas deriva de la especial forma de trabar la muralla con las estructuras interiores, que recuerda las murallas púnicas de compartimentos, de las cuales Qart Hadasht constituye el ejemplo más cercano. En la cortina de la zona del Molinete los muros perpendiculares intestan con una muralla de entre 0,75 y $1 \mathrm{~m}$ de ancho. También como en el Tossal, la fortificación actúa como gran muro de aterrazamiento aprovechando el desnivel. En cuanto a la fábrica, el paramento se compone de un zócalo construido con mampuestos irregulares trabados con barro y dispuestos en hiladas de tendencia horizontal, sobre el que apoyaba un alzado realizado con adobes recubiertos mediante una fina capa de mortero de cal (Noguera et $a l ., 2017)$. La diferencia principal está en las estancias interiores, que son simples y no dúplices, como en el caso del fortín alicantino.

Hace algunos años apuntábamos que la peculiaridad de algunos recintos fortificados del ámbito ibérico durante las décadas finales del siglo II y el siglo I a. C. podría señalar modelos de implantación romano republicanos aun por tipificar, pues se apartaban de lo que se solía considerar "romano" (Morillo 2004, pp. 205-206). Uno de los mayores avances de la arqueología militar romana en estos años ha sido precisamente distinguir esos nuevos modelos romanos entre los enclaves considerados ibéricos. Son de reducidas dimensiones -rara vez superan 1 ha- y se localizan en posiciones topográficas dominantes sobre el entorno, lo que implica una función de control territorial, bien por cuestiones estratégicas, bien por explotación de recursos. Sin embargo, existen diferencias notables de carácter estructural entre ellos, tanto en su forma como en las fábricas constructivas. Su fisonomía y la presencia en muchos de restos de armas e indumentaria militar romana ha llevado a considerarlos pequeños fuertes o fortines, si bien algunos investigadores han optado por denominarles genéricamente como castella, termino muy bien tipificado en la literatura científica para fuertes auxiliares de época altoimperial y que puede dar lugar a cierta confusión si no se emplea con propiedad (Morillo 2016, pp. 12-13).

El recinto del Tossal de la Cala se incluye, sin duda, en esta categoría. Como hemos señalado, entre estos fortines existen notables diferencias respecto a las plantas, ya que la adaptación a la topografía es lo habitual. Sin embargo, las semejanzas son notables, en sus defensas y en estructuras interiores, con parecidos esquemas de modulación romanos. Citaremos por similitud el recinto del Cerro del Trigo (Puebla 
de Don Fadrique, Granada), con su estructura quasi rectangular de algo más de media hectárea y $157 \mathrm{~m}$ de eje longitudinal. La muralla oscila entre 0,90 y $1 \mathrm{~m}$ de ancho y está construida mediante doble paramento de piedra caliza careada y regularizada y un relleno interior de tierra y guijarros. En el extremo occidental, protegiendo uno de los accesos, una torre o bastión dividida en tres espacios modulares se proyecta fuera de la línea de la muralla. Otras dependencias interiores, que también emplean la muralla como pared perimetral, presentan un aspecto de módulos divididos en dos dependencias interpretados como barracones. El yacimiento parece estar en uso durante la mayor parte del siglo I a. C. hasta época de Augusto (Adroher $e t$ al., 2006, pp. 627-629).

En la misma zona del sudeste, los recintos de La Cabezuela de Barranda y el Cerro de las Fuentes de Archivel (Caravaca de la Cruz, Murcia) datados a mediados del siglo I a. C. guardan también algunas semejanzas (Brotons y Murcia, 2008). Ambos son poligonales, con muros de 0,60 a $0,80 \mathrm{~m}$ de ancho y alzado de tapial, el primero, $\mathrm{y}$ cortinas de entre $1,37 \mathrm{y}$ $1,82 \mathrm{~m}$ y también alzado de tapial el segundo. Restos de dependencias aparentemente en batería con muros perpendiculares a la muralla se documentan en la Cabezuela de Barranda.

También apreciamos similitudes en el fortín de Puig Castellar (Biosca, Lleida) fechado entre los años 180-120 a. C. (Pera et al., 2019, pp. 30-37). Su muralla presenta características semejantes, con un ancho entre 1 y $1,20 \mathrm{~m}$ y una fábrica de mampostería de disposición más o menos regular, con un relleno interior de tierra y yeso. También aquí las partes altas de la fortificación, hasta unos $5 \mathrm{~m}$, serían de tapial. Una batería de estancias dobles modulares se adosa a la cara interna del lienzo sur de la muralla. En la misma área, el asentamiento militar de Monteró (Camarasa, La Noguera, Lleida), datado entre finales del siglo II e inicios del I a. C., también es comparable en lo relativo a la muralla y estancias en batería identificadas con barracones (Principal, Camañes y Padrós, 2015, pp. 311-315).

Como hemos visto, los asentamientos con semejanzas con el Tossal de la Cala presentan una clara vinculación militar y una cronología que se extiende entre las últimas décadas del siglo II hasta mediados del siglo I a. C., un momento de profundos cambios y transformaciones en la castrametación militar, que coincide además con episodios de intensa actividad bélica en la península ibérica (Morillo y Sala 2019, pp. 59-60). Que los fortines de la costa alicantina se vinculen a las guerras sertorianas lo confirma, además del contexto material, el hecho estratigráfico de su construcción ex novo, sobre roca, y que presenten un único horizonte de ocupación. La presencia de contingentes del ejército romano en la franja costera de la Contestania, pueblo aliado con Sertorio (Liv. Per. XCI), debió responder a las necesidades de aprovisionamiento de las tropas y, no en vano, Sertorio eligió Dianium (Dénia) como base naval (Strab. III, 4, 6; Sal., Hist. I, 124; Cic. Ver. II, 5, 146, 151 y 154). Teniendo en cuenta que los puertos de Tarraco y Carthago Nova estaban en manos senatoriales, la disposición de los fortines indica que vigilar el tránsito de naves en torno al cabo de la Nao, con un control visual del espacio marítimo hasta la vecina Ibiza, debió ser fundamental para los intereses de Sertorio. En este sentido, la alianza con los piratas cilicios le proporcionaría los agentes necesarios para interceptar las naves comerciales senatoriales en ataques rápidos e inesperados. La abundancia de ánforas y otros vasos foráneos en los fortines, y en el Tossal de la Cala en especial, solo se explica por actuaciones de la flota pirata contra naves cargadas con el abastecimiento para el ejército senatorial (Sala, Bayo y Moratalla, 2013, pp. 202-205). Conocer la estrategia de Sertorio nos ha hecho comprender que el litoral alicantino se convierte en un tramo costero decisivo cada vez que existen conflictos, de carácter bélico o no, pero con el mar occidental como escenario de actuaciones. Por su cercanía a la costa argelina y la vecindad de Ibiza y Cartagena, la costa alicantina también estuvo jalonada de puntos de vigilancia durante la segunda guerra púnica, y no por casualidad situados en cerros muy próximos a los fortines sertorianos.

Concluimos presentando una línea de investigación que se inicia ahora. El hecho de que tanto el Tossal de la Cala como otros fortines similares se aparten del modelo de campamento canónico tal vez esté en relación con tropas de origen hispano ya perfectamente asimiladas a los modelos culturales romanos, pero integradas como auxiliares en el ejército romano en razón de su categoría jurídica. La mayoría de las tropas sertorianas parecen ser de este origen. Llegar a distinguir entre patrones materiales "legionarios" y "auxiliares" ofrece grandes posibilidades ante la relectura de viejos registros como Cáceres el Viejo ${ }^{29}$ y el descubrimiento de nuevas realidades arqueológicas, como el fortín de Cáceres Viejo en la sierra cacereña de Santa Marina (Pereira y Días 2020), que se añaden a la materialidad de la red de fortines sertorianos en la costa norte alicantina.

29 Trabajo en preparación de un nutrido equipo de investigadores dirigido por C. Pereira y A. Morillo (eds.): El campamento de Cáceres el Viejo. Una nueva aproximación de conjunto. 


\section{BIBLIOGRAFÍA}

Abad, L. (1987). "El poblamiento ibérico en la provincia de Alicante". En: Iberos. I Jornadas sobre el Mundo Ibérico. Jaén: Ayuntamiento de Jaén - Junta de Andalucía, pp. 157-169.

Adam, J. P. (1982). L'architecture militaire grecque. Paris: Picard.

Adroher, A. M., Caballero, A., Sánchez, A., Salvador, J. A. y Brao, F. J. (2006). "Estructuras tardorrepublicanas en el ámbito rural de la Bastetania”. En: Morillo, Á. (Ed.). Arqueología Militar romana en Hispania. Producción y abastecimiento en el ámbito militar. León: Universidad de León, pp. 625-638.

Asensio Esteban, J. A. (2006). "El gran aparejo en piedra en la arquitectura de época romana republicana en la provincia Hispania citerior: el opus siliceum y el opus quadratum". Salduie, 6, pp. 117-159.

Bats, M. (1988). Vaisselle et alimentation à Olbia de Provence (v. 350-V. $50 \mathrm{av}$. JC.). Modèles culturels et catégories céramiques. Revue archéologique de Narbonnaise, supplément au tome 18. Paris: CNRS.

Bayo, S. (2010). El yacimiento Ibérico de "El Tossal de la Cala". Nuevo estudio de los materiales depositados en el Marq correspondientes a las excavaciones de José Belda y Miquel Tarradell. Serie Trabajos de Arqueología del MARQ, 1. Alicante: Museo Arqueológico Provincial Marq.

Bayo, S. (2014). "Identificación del uso del espacio y su momento histórico a partir de los contextos materiales". En: Sala, F. y Moratalla, J. (Eds.). Las Guerras Civiles romanas en Hispania: una revisión histórica desde la Contestania. Alicante: Marq - Universidad de Alicante, pp. 99-113.

Bayo, S. (2018). Contestania ibérica en los siglos II-I a.n.e.: poblamiento y romanización. Tesis doctoral, Universidad de Alicante. http://hdl.handle.net/10045/99256

Belda, J. (1945). "Un busto de Tanit báquica de Benidorm". En: Congreso de Arqueología del Sudeste I, Cartagena, 1945. Murcia: Museo Arqueológico de Murcia, pp. 216-217.

Belda, J. (1950-1951). "Museo Provincial de Alicante. Nuevos ingresos". Memorias de los Museos Arqueológicos Provinciales, XI-XII, pp. 79-105.

Bellón, J. P., Ruiz, A., Molinos, M, Rueda, C., Gómez, F. y Quesada, F. (2015). "Conclusiones y propuestas sobre el desarrollo de la batalla de Baecula”. En: Bellón, J. P., Ruiz, A., Molino, M., Rueda, C. y Gómez, F. (Eds.). La Segunda Guerra Púnica en la Península Ibérica. Baecula, arqueología de una batalla. Jaén: Universidad de Jaén: pp. 537-599.

Beltrán, M. (2002). Ab ovo ad mala: cocina y alimentación en el Aragón romano. Zaragoza: Institución "Fernando el Católico" (CSIC).

Bolla, M., Boube, C. y Guillaumet, J. P. (1991). "Les situles". En: Feugère, M. y Rolley, C. (Eds.). La vaisselle tardo-républicaine en bronce.Publications du Centre des recherches sur techniques gréco-romaines, 13. Dijon: Centre des recherches sur techniques gréco-romaines, pp. 10-22.
Boube, C. (1991). "Les cruches”. En: Feugère, M. y Rolley, C. (Eds.). La vaisselle tardo-républicaine en bronze. Publications du Centre des recherches sur techniques gréco-romaines, 13. Dijon: Centre des recherches sur techniques gréco-romaines, pp. 23-45.

Broconi, P. (2001). "Emplecton". Annali di Archeologia e Storia Antica, Nuova Serie, 8, pp. 105-118.

Brotons, F. y Murcia, A. (2008). "Los castella republicanos romanos de la cuenca alta de los ríos Argos y Quípar (Caravaca, Murcia). Aproximación arqueológica e histórica". En: García-Bellido, M. ${ }^{\text {a }}$ P., Mostalac, A. y Jiménez, A. (Eds.). Del Imperium de Pompeyo a la Autoritas de Augusto. Anejos de Archivo Español de Arqueología, XLVII. Madrid: CSIC, pp. 49-66.

Brouquier-Reddé, V. y Deyber, A. (2003). "Fourniment, harnachement, quincaillère, objets divers". En: Reddé, M. y Schnurbein, S. von (Dirs). Alèsia. Fouilles et recherches franco-allemandes sur les travaux militaires romains autour du Mont-Auxois(1991-1997), 2. Paris: L'Académie des Inscriptions et Belles-Lettres, pp. 293-333.

Burillo, F. (1980). El valle medio del Ebro en época ibérica: contribución a su estudio en los ríos Huerva y Jiloca Medio. Zaragoza: Institución Fernando el Católico.

Burillo, F. (2009). "Estructuras de almacenaje en el valle medio del Ebro y sistema ibérico central durante el primer milenio a.C.”. En: García, R. y Rodríguez, D. (Eds.). Sistemas de almacenamiento entre los pueblos prerromanos peninsulares. Cuenca: Universidad de Castilla-La Mancha, pp. 315-350.

Burillo, F., Cano, M. A. y Saiz, E. (2008). "La cerámica celtibérica”. En: Bernal, D. y Ribera, A. (Eds.). Cerámicas hispanorromanas. Un estado de la cuestión. Cádiz: Universidad de Cádiz, pp. 171-187.

Carreras, C., Martin, A., Pera, J. y Rodrigo, E. (2016). "Las ánforas de Brindisi en la Hispania Citerior. Pautas de distribución y consumo". Sagvntvm, 48, pp. 103-121. DOI: https://doi.org/10.7203/sagvntvm.48.7671

Cera, G. y Quilici Gigli, S. (Eds.) (2001). Fortificazioni antiche in Italia. Età republicana. Roma: L'Erma di Bretschneider.

Connolly, P. (1997). "Pilum, gladius and pugio in the late republic". En: Feugère, M. (Dir.). L'équipement militaire et l'armement de la république (Ive-Ier s. Avant J.-C.), Journal of Roman Military Equipment Studies 8, pp. 41-57.

Dedet, B. (2012). Ambrussum, Hérault: Un quartier de la nécropole du second âge du fer. Bibliothèque d'archéologie méditerranéenne et africaine, 11. París: Publications du Centre Camille Jullian, Éditions Errance.

Desy, Ph. (1989). Les timbres amphoriques de l'Apulie républicaine. BAR Int. Ser., 554. Oxford: BAR Publishing.

Doménech, C. (2014). "El conflicto sertoriano en el sureste peninsular a través de los registros numismáticos". En: Sala, F. y Moratalla, J. (Eds.). Las Guerras Civiles romanas en Hispania: una revisión histórica desde la Contestania. Alicante: Marq-Universidad de Alicante, pp. 91-97.

Erice, R. (2007). "La vajilla de bronce en Hispania". Sautuola, XIII, pp. 197-216.

García y Bellido, A. (1945). La arquitectura entre los iberos. Madrid: Publicaciones de la Universidad de Madrid. 
García Hernández, F, (1986). El yacimiento ibérico del Tossal de la Cala (Benidorm). Los materiales arqueológicos depositados en el Museo Arqueológico Provincial de Alicante.Memoria de licenciatura, Universidad de Alicante. http://www.marqalicante.com

Goldsworthy, A. (2003). The complete Roman Army. London: Thames \& Hudson Ltd.

Hellmann, M. C. (2010). L'architecture grecque. 3. Habitat, urbanisme et fortifications. Paris: Picard.

Huguet, E. (2013). "El material más usado por los antiguos: la cerámica común y de cocina". En: Ribera, A. (Coord.). Manual de cerámica romana: del mundo helenístico al Imperio Romano. Madrid: Comunidad de Madrid / MAR, pp. 291-330.

Jacques, A. y Prilaux, G. (2008). “ARRAS-les fouilles Actiparc. Le mobilière à caractère militaire découverte dans un vaste complexe césaro-tibérien”. En: Poux, M. (Ed.). Sur les Traces de César. Militaria tardo-républicains en contexte gaulois. Glux-en-Glenne: Bibracte, Centre archéologique européen, pp. 47-62.

Lejavitzer, A. (2005). "Entre cazuelas y salazones: sala cattabia en Apicio IV, I, 1-3”. NouaTellus, 23 (1), pp. 149-163.

Llobregat, E. A.(1972). Contestania ibérica. Alicante: Instituto de Estudios Alicantinos.

Lugli, G. (1957). La técnica edilizia romana con particolare riguardo a Roma e Lazio. Roma: Scienze e Lettere.

Luik, M. (2002). Die Funde aus den Römischen Lagern um Numantia im Römisch-Germanichen Zentralmuseum. Kataloge Vor-und Frühges-chichtlicher Altertümer, 31. Bonn, Mainz: RGZM/Habelt.

Manacorda, D. (1994). "Produzione agricola, produzione ceramica e proprietà della terra nella Calabrìa romana tra Repubblica e Impero". Epigrafia della produzione e della distribuzione, 193, pp. 3-59.

Mansel, K. (2004). "Vajilla de bronce en la Hispania republicana”. En: Olmos, R. y Rouillard, P. (Eds.). La vajilla ibérica en época helenística (siglos IV-III al cambio de era). Collection de la Casa de Velázquez, 89. Madrid: Casa de Velázquez, pp. 19-30.

Marín, C., Ribera, A. y Serrano, M. L. (2004). "Cerámica de importación itálica y vajilla ibérica en el contexto de Valentia en la época sertoriana”. En: Olmos, R. y Rouillard, P. (Eds.). La vajilla ibérica en época helenística: siglos IV-III al cambio de era. Madrid: Casa de Velázquez, pp. 113-134.

Mariné, M. (2001). Fíbulas romanas en Hispania: La meseta. Anejos de Archivo Español de Arqueología, XXIV. Madrid: CSIC.

Milne J. S. (1970). SurgicalInstruments in Greek and Roman Times. New York: Augustus M. Kelley, Publishers. [1 ${ }^{\mathrm{a}}$ ed., London: At The Clarendon Press, 1907].

Moratalla, J. (2005). "El territorio meridional de la Contestania”. En: Abad, L., Sala, F. y Grau, I. (Eds.). Contestania Ibérica, treinta años después. Alicante: Universidad de Alicante, pp. 91-118.

Morillo, A. (2004). "Romanización y fortificación: algunas cuestiones de concepto". En: Moret, P. y Chapa, T. (Eds.). Torres, atalayas y casas fortificadas. Explotación $y$ control del territorio en Hispania (s. III a. C.-siglo Id. C.). Jaén: Universidad de Jaén, pp. 205-207.
Morillo, A. (2014). "Campamentos y fortificaciones romanas en Hispania durante la primera mitad del siglo I a.C.: calibrando a Sertorio". En: Sala, F. y Moratalla, J. (Eds.). Las Guerras Civiles romanas en Hispania: una revisión histórica desde la Contestania. Alicante: Marq - Universidad de Alicante, pp. 35-49.

Morillo, A. (2015). "Lucernas romanas en Hispania: entre lo utilitario y lo simbólico". En: Fernández Ochoa, C., Morillo, A. y Zarzalejos, M. (Eds.). Manual de Cerámica Romana II. Cerámicas romanas de época altoimperial en Hispania. Importación y producción. Alcalá de Henares: Museo Arqueológico de la Comunidad de Madrid - Colegio de Doctores y Licenciados en Filosofía y Letras y en Ciencias de la Comunidad de Madrid, pp. 321-428.

Morillo, A. (2016). "Campamentos y fortificaciones tardorrepublicanas en Hispania. Una nueva línea de investigación en arqueología militar romana”. En: Pera, J. y Vidal, J. (Eds.). Fortificaciones y control del territorio en la Hispania republicana. Zaragoza: Libros Pórtico, pp. 1-51.

Morillo, A. y Sala, F. (2019). "The Sertorian Wars in the conquest of Hispania: from data to archaeological assesment”. En: Fitzpatrick, A. F. y Haselgrove, C. (Eds.). Julius Caesar's Battle for Gaul. New Archaeological Perspectives. Oxford/Philadelphia: Oxbow Books, pp. 49-72.

Muñoz Amilibia, A. M. (1963). Pebeteros ibéricos en forma de cabeza femenina. Instituto de Arqueología de la Universidad de Barcelona, 5. Barcelona: Universidad de Barcelona.

Noguera, J. M., Madrid, M. J., García, M. V. y Velasco, V. (2017). "Las defensas de Cartagena en la antigüedad: las murallas de la acrópolis en los siglos III y II a.C.". En: Prados, F. y Sala, F. (Eds.). El Oriente de Occidente. Fenicios y púnicos en el área ibérica. Alicante: CFYP - Universidad de Alicante, pp. 347-383.

Nordström, S. (1969). I. La céramique peinte ibérique de la province d'Alicante. Acta Universitatis Stockolmiensis. Estocolmo: Universidad de Estocolmo - Almquist \& Wiksell.

Olcese, G. (2003). Le ceramiche comuni a Roma e in area romana: Produzione, circolazione e tecnologia (Tarda età Repubblicana-Prima età Imperiale). Mantova: Ed. SAP Società Archeologica s.r.1.

Olcina Cantos, J. (2004). "Riesgo de inundaciones y ordenación del territorio en la escala local: el papel del planeamiento urbano municipal". Boletín de la Asociación de Geógrafos Españoles, 37, pp. 49-84.

Pera, J., Carreras, C., Romaní, N., Rodrigo, E., Padrós, C. y de Solá, G. (2016). "El proceso de implantación territorial romana en el NE de la provincia Citerior en el siglo II a. C. Análisis de los tres modelos de ocupación: Ilturo, Can Tacó y Puig Castellar de Biosca”. En: Pera, J. y Vidal, J. (Eds.). Fortificaciones y control del territorio en la Hispania republicana. Zaragoza: Libros Pórtico, pp. 167-205.

Pera, J., Rodrigo, E., Romaní, N. y Carreras, C. (2019). "Puig Castellar de Biosca (Lleida). Una fortificación romana del siglo II a. C. en el noreste de la Hispania Citerior". Gladius, XXXIX, pp. 19-43. DOI: https://doi.org/10.3989/gladius.2019.02 
Pereira, C. y Dias, I. (2020). "Acciones y reacciones: evidencias de los conflictos civiles romanos en Extremadura. El caso de Sierra de Santa Marina, Cáceres Viejo (Cáceres, España)". Archivo Español de Arqueología, 93, pp. 103-126.

DOI: https://doi.org/10.3989/aespa.093.020.005

Price, J. (1981). Roman glass in Spain: a catalogue of glass found at the Romans towns of Tarragona, Merida, Italica and Carmona, with a discussion of the vessel forms from these towns and other roman sites in Spain. Boston Spa, Wetherby: The British Library Document Supply Centre.

Principal, J., Camañes, M. P. y Padrós, C. (2015). “Un edifici singular al castellum tardorepublicà de Monteró I (Camarasa, la Noguera), i l'urbanisme complex d'un post avançat del nord-est de la Citerior'. Revista d'Arqueología de Ponent 25, pp. 309-325.

Quesada, F. (2007). "Hispania y el ejército romano republicano. Interacción y adopción de tipos metálicos". Sautuola, XIII, pp. 379-401.

Quesada, F., Gómez, F., Molinos, M. y Bellón, J. P. (2015). "El armamento hallado en el campo de batalla de Las Albahacas-Baecula". En: Bellón, J. P., Ruiz, A., Molino, M., Rueda, C. y Gómez, F. (Eds.). La Segunda Guerra Púnica en la Península Ibérica. Baecula, arqueología de una batalla. Jaén: Publicaciones de la Universidad de Jaén, pp. 311-396.

Quilici, L. y Quilici Gigli, S. (2001). "Sulle mura di Norba". En: Cera, G. y Quilici Gigli, S. (Eds.). Fortificazioni antiche in Italia. Età republicana. Roma: L'Erma di Bretschneider, pp. 181-244.

Ramón, J. (1995). Las ánforas fenicio-púnicas del Mediterráneo central y occidental. Col·lecció Instrumenta, 2. Barcelona: Universitat de Barcelona.

Ramón, J. (2008). "El comercio púnico en occidente en época tardorrepublicana (siglos -II/-I). Una perspectiva actual según el tráfico de productos envasados en ánforas". En: Uroz, J., Noguera, J. M. y Coarelli, F. (Eds.). Iberia e Italia: modelos romanos de integración territorial. Murcia: Tabularium, pp. 67-100.

Ribera, A. (1998). La fundació de València. La ciutat a l'època romanorepublicana (segles II-I a. de C.). Estudios universitarios, 71. Valencia: Edicions Alfons El Magnànim.

Ribera, A. y Marín, C. (2004-2005). "Las cerámicas del nivel de destrucción de Valentia (75 a.n.e.) y el final de Azaila". Kalathos,22-23, pp. 271-300.

Ricci, M. (1974). "Per una cronología delle lucerne tardo-repubblicane". Rivista di Studi Luguri, XXXIX (2-4), pp. 168-234.

Roth, J. P. (1999). The logistics of de Roman Army at war (264 B.C.-A.D. 235). Columbia Studies in the Classical Tradition, XXIII. Leiden/Boston/Köln: Brill.

Saiz, M. E. y López, R. (2011). "Aplicación de las herramientas SIG en el estudio de la producción cerámica celtibérica de los alfares del entorno del río Piedra". En: Actas del V Simposio Internacional de Arqueología de
Mérida "Sistemas de Información Geográfica y Análisis Arqueológico del territorio". Anejos de Archivo Español de Arqueología, LIX. Mérida: CSIC, pp. 99-112.

Sala Sellés, F. (2003). "La transformación del instrumentum domesticum y el comercio". En: Abad, L. (Ed.). De Iberia in Hispaniam. La adaptación de las sociedades ibéricas a los modelos romanos. Alicante: Universidad de Alicante, pp.287-315.

Sala Sellés, F., Abad, L., Bayo, S. y Doménech, C. (2014). "Las huellas de las guerras sertorianas en el sureste de Hispania”. En: Cadiou, F. y Navarro, M. (Eds.). La guerre et ses traces dans la péninsule Ibérique. Conflicts et Sociétés en Hispanie à l'époque de la conquête romaine (IIIe-Ier siècle av. J. C.). Ausonius Mémoires, 37. Burdeos: Ausonius, pp.181-202.

Sala Sellés, F., Bayo, S. y Moratalla, J. (2013). "Dianium, Sertorio y los piratas cilicios. Conquista y romanización de la Contestania ibérica". En: Álvarez-Ossorio, A., Ferrer, E. y García Vargas, E. (Eds.). Piratería y Seguridad Marítima en el Mediterráneo Antiguo. Spal Monografías, XVII. Sevilla: Universidad de Sevilla, pp.187-208.

Sala Sellés, F., Moratalla, J. y Abad, L. (2014). "Los fortines de la costa septentrional alicantina: una red de vigilancia de la navegación”. En: Sala, F. y Moratalla, J. (Eds.). Las Guerras Civiles romanas en Hispania: una revisión histórica desde la Contestania. Alicante: Marq - Universidad de Alicante, pp.79-89.

Salido, J. (2017). "Los dolia en Hispania: caracterización, funcionalidad y tipología”. En: Fernández Ochoa, C., Morillo, A. y Zarzalejos, M. (coords.). Manual de cerámica romana, III. Madrid: Museo Arqueológico de la Comunidad de Madrid - Colegio de Doctores y Licenciados en Filosofía y Letras y en Ciencias de la Comunidad de Madrid, pp. 238-309.

Tarradell, M. (1985). "El poblat ibèric del Tossal de la Cala de Benidorm. Notes d'excavació". Fonaments, V, pp. 113-119.

Tchernia, A. (1986). Le vin de l'Italie romaine. Essai d'histoire économique d'après les amphores. Bibliothèque des Écoles françaises d'Athènes et de Rome, 261. Roma: École française de Rome.

Ulbert, T. (1984). Cáceres el Viejo. Ein Späterepublickanisches Legionslager in Spanisch-Extremadura. Madrider Beiträge, XI. Mainz: Philipp von Zabern.

Ulrich, R.B. (2007). Roman Woodworking. New Haven, CT: Yale University Press.

Uroz, H. (2012). Prácticas rituales, iconografía vascular y cultura material en Libisosa (Lezuza, Albacete). Nuevas aportaciones al Ibérico Final del Sudeste. Alicante: Universidad de Alicante - Cajasol Obra Social.

Vicente, J.D., Punter, M.P. y Ezquerra, B. (1997). "La catapulta tardo-republicana y otro equipamiento militar de 'La Caridad' (Caminreal, Teruel)". Journal of Roman Military Equipment Studies, 8, pp. 167-199.

Yáñez, A. (2000). Historia y descripción de Benidorm. Alicante: Gráficas Díaz. 